\title{
Marine Natural Products Research: Current Directions and Future Potential
}

\author{
Gabriele M. König ${ }^{1,2}$ and Anthony D. Wright ${ }^{1}$ \\ ${ }^{1}$ Institute for Pharmaceutical Biology, Technical University of Braunschweig, Mendelssohnstraße 1, D-38106 Braunschweig, Germany \\ ${ }^{2}$ Address for correspondence
}

Received: November 16, 1995; Accepted: November 25, 1995

\begin{abstract}
Natural products research is increasingly turning to marine animals, plants, and microbes as source organisms. Several marine natural products are currently in preclinical and clinical evaluation, others show promising biological activities in in vitro and in vivo assays. Investigations of biological and chemical ecological phenomena in the marine world will contribute to a better understanding of marine habitats, and also provide a more founded basis regarding the search for pharmaceutically useful marine natural products.
\end{abstract}

Key words: Marine biotechnology, marine chemistry, sponges, marine microbes, marine fungi, symbiosis.

\section{Introduction}

Through improved biological screening methods, the role of natural products in drug discovery has been greatly enhanced in the last few years (1). This is particularly true for marine natural products, which show an interesting array of diverse and novel chemical structures with potent biological activities (2). Biological and chemical investigations of marine ecosystems have, over the last decade, provided insights into a wonderful and complex world underwater. These insights are capable of benefiting both applied and basic research and this work has posed many questions, a direct result of which is that many new areas of research have, or are in the process of being, developed.

Before embarking upon a discussion of the possible future directions that marine natural products research may take, it is important to highlight some details of topics that are of current importance in this research field. Thus, we briefly describe the most important pharmacologically active marine compounds, which are in either preclinical or clinical evaluation, and/or active towards important clinical targets e.g., immunosuppression. We also briefly discuss mechanism-based bioassays. The chemical diversity within species is then reviewed using some pertinent examples to highlight the present status of this area as well as possible future directions. Marine micro-organisms are then discussed with respect to their biochemical potential and the understanding of their relationship to their host organisms. Finally, a number of conclusions are

Planta Medica 62 (1996) 193-211

(c) Georg Thieme Verlag Stuttgart · New York drawn concerning the future prospects of the very fertile research area of marine-related natural products.

\section{Compounds in Preclinical and Clinical Evaluation}

Research into the pharmacological properties of marine natural products has led to the discovery of many potently active agents considered worthy for clinical application. Arabinose-nucleosides, known since the 1950 s as constituents of the Caribbean sponge Cryptotethya crypta (Tethyidae), have led researchers to synthesise analogues, ara-A (Vidarabin, Vidarabin Thilo ${ }^{\circledR}$ ) and ara-C (Cytarabin, Alexan ${ }^{\circledR}$, Udicil $\left.{ }^{\circledR}\right)$, with improved antiviral and anticancer activity $(2,3)$. Currently, these are the only marine related compounds in clinical use. Considering the importance of nucleoside-analogues in antiviral and anticancer therapy, e.g., 3'-azido-3'-deoxythymidine (AZT, zidovudin), the original discovery of Bergmann et al. (4) can be considered one of immense significance.

In recent years many marine natural products which are promising candidates for new drugs have been discovered. The sesterterpenoid manoalide (1), obtained from the sponge Luffariella variabilis (Thorectidae), was detected in a program searching for new anti-inflammatory compounds. It proved to be a potent inhibitor of phospholipase $A_{2}\left(P_{L} A_{2}\right)\left(P L A_{2}\right.$ from bee venom $\left.I C_{50}=0.05 \mu \mathrm{M}\right)$ resulting in reduced arachidonic acid release. Inhibition of phospholipase C (PLC) (phosphatidylinositolspecific PLC from guinea-pig uterus $\mathrm{IC}_{50}=1.5 \mu \mathrm{M}$ ) and the ability of manoalide to function as a calcium channel blocking agent allows this compound to be used in the study of the role of calcium mobilisation in inflammatory processes and, in a more general sense, in signal transduction pathways. Manoalide has thus become a useful biochemical tool. A significant number of manoalide derivatives have been synthesised and evaluated for their biological activity. Clinical trials are currently under way with some of these, and it is probable that a manoalide-inspired derivative will eventually reach the market (5-8).

Pseudopterosins are a series of tricyclic diterpene glycosides from the Caribbean gorgonian Pseudopterogorgia elisabethae (Gorgoniidae), discovered by Fenical et al. (9). Pseudopterosin $\mathrm{E}(\mathbf{2})$ is the one with the best pharmacological profile, combining low toxicity and potent anti-inflammatory activity. Its mechanism of action has been partially investigated and involves antagonistic activities of pseudopterosin $E$ towards enzymes of the arachidonic acid cascade, e.g., lipoxygenases. In 
human neutrophils, pseudopterosin $E$ inhibits degranulation and formation of leukotrienes $(8,10)$. In 1991, phase I clinical trials were initiated with pseudopterosin $\mathrm{E}$ as a topical antiinflammatory agent (11).

The bryostatins were first discovered some 20 years ago in the bryozoan Bugula neritina (Bugulidae) by the Pettit group. Problems with supply of sufficient quantities of these natural products hampered the study of this interesting group of marine metabolites for many years. Bryostatin 1 (3) has just completed phase I clinical trials in the USA (12) and is in phase II trials in Europe as an anti-cancer agent (13). The compound affects protein kinase $C$ activity, which may be the mechanistic basis for both the observed anticancer and immunostimulating activity (14).

Didemnin B (4), one of a family of depsipeptides, obtained by Rinehart et al., from the tunicate Trididemnum solidum (Didemnidae), has antiviral, immunosuppressive, and potent cytotoxic properties. The compound is too toxic to be useful as an antiviral or immunosuppressive agent, but has been in phase I clinical trials as an anticancer agent (15). Even though it was potently cytotoxic in in vitro and in vivo models no clinical efficacy has yet been established (16). Phase II clinical trials are currently underway $(11,13)$.

For dolastatin 10 (5), a peptide produced by the sea hare Dolabella auricularia (Alysiidae), and ecteinascidins, e.g., 6, alkaloids isolated from the tunicate Ecteinascidia turbinata (Perophoridae) (15), clinical trial applications are pending. Halomon (7), a polyhalogenated acyclic monoterpene from the red alga Portieria hormemannii (Rhizophyllidacae), shows promising differential cytotoxicity towards certain tumour cell lines, and is currently in preclinical evaluation. At the same stage of development is halichondrin $\mathbf{B}(\mathbf{8})$, a polyether macrolide isolated from several sponge species $(12,13)$.

\section{Therapeutic Targets}

\section{Marine natural products with immunosuppressive activity}

Marine natural products have been investigated predominantly for their antimicrobial, cytotoxic, antitumour, antiviral, and anti-inflammatory properties. Success in these areas is demonstrated by the agents now in pre- or clinical evaluation.

One of the emerging therapeutic areas in which potentially useful compounds have been identified is that of immunosuppressive activity. Due to the now recognised autoimmune mechanism of many diseases such as rheumatoid arthritis, psoriasis, multiple sclerosis and, additionally the extensive practice of organ and tissue transplantations, it is evident that immunosuppressive agents are of major clinical importance. Currently, there are few immunosuppressants on the market, e.g., cyclosporine (Cyclosporine A. Sandimmum ${ }^{\circledR}$ ) and FK506 (Tacrolimus, Prograf ${ }^{\circledR}$ ). Few marine natural products have been described as having immunosuppressive activity. The acridine alkaloid dercitin (9) occurs in tunicates and has also been found in the deep water sponge Dercitus sp., (Pachastrellidae). Dercitin shows immunosuppressive activity in a murine derived, two-way mixed lymphocyte reaction (MLR) assay (0\% MLR, $0.01 \mu \mathrm{g} / \mathrm{ml}$ ). This compound is, however, highly cytotoxic with in vivo antitumour activity and thus more likely to be applied in cancer therapy $(3,17)$. A further sponge metabolite, the hexacyclic bisguanidine alkaloid palau'amine (10) from Stylotella agminata (Hymeniacidonidae), was reported to have an $\mathrm{IC}_{50}<18 \mathrm{ng} / \mathrm{ml}$ in the MLR, while cytotoxicity towards murine lymphocytes was determined to be $\mathrm{IC}_{50}=1.5 \mu \mathrm{g} / \mathrm{ml}$. Data on in vivo activity of this compound are currently unavailable (18). Weak in vitro immunosuppressive activity was determined for the sterol $4 \alpha$-methyl-5 $\alpha$-cholest-8-en-3 $\beta$-ol and the pyrrole derivative 4,5-dibromo-2-pyrrolic acid isolated from the sponge Agelas flabelliformis (Agelasidae) (19). The sacoglossan mollusc Elysia rufescens (Elysiidae) and its predominant dietry source the green alga Bryopsis sp., (Bryopsidaceae), contain the depsipeptide kahalalide $F(\mathbf{1 1})$. This compound shows selective antitumour activity towards solid tumour cell lines and a weak immunosuppressive activity in the MLR assay $\left(\mathrm{IC}_{50}=3 \mu \mathrm{g} / \mathrm{ml}\right)(20)$.

The most promising candidates for immunosuppressive therapy, among marine natural products, are discodermolide (12) and microcolin A (13). Discodermolide is one of the many structurally varied metabolites found in Discodermia spp., (Discodermiidae). It is a polyhydroxylated lactone with a hitherto unprecedented carbon skeleton (21). Even though the extract of $D$. dissoluta was only weakly immunosuppressive, with a far more pronounced cytotoxicity, the isolated pure natural product discodermolide exhibited potent suppressive activity in the murine two-way MLR and concanavalin A stimulation of splenocyte cultures, $\mathrm{IC}_{50}$ values being 0.24 and $0.19 \mu \mathrm{M}$, respectively. Discodermolide also suppressed the proliferation of human peripheral blood leucocytes in the two-way MLR, with an $\mathrm{IC}_{50}$ of $5.65 \mu \mathrm{M}$. It was not toxic to human peripheral blood lymphocytes at relevant concentrations $(<80.6 \mu \mathrm{M})$. Studies on its mechanism of action are not conclusive at this time, but most importantly, however, is the fact that it appears to differ from that of cyclosporine A. Discodermolide does not inhibit interleukin-2 (IL-2) production but appears to modulate the expression of the IL-2 receptor (22). It was also tested in vivo using the graft-versus-host rejection splenomegaly assay. At a concentration of $1.25 \mathrm{mg} / \mathrm{kg} 93 \%$ suppression of the immune response with no associated morbidity was achieved. In comparison, mice treated with $150 \mathrm{mg} / \mathrm{kg}$ of cyclosporine A showed $80 \%$ suppression of the splenomegaly response (23).

Microcolins are lipopeptides isolated from a strain of the bluegreen alga Lyngbya majuscula (Oscillatoriaceae), collected off the coasts of Venezuela and Miami. These compounds resemble majusculamide $\mathrm{D}$ and deoxymajusculamide $\mathrm{D}$, which were isolated from another chemovariant of the same species. Shipboard assays on the ethanolic extract of this blue-green alga, revealed cytotoxic and immunosuppressive activity. Subsequent bioassay-guided fractionation of this extract led to the isolation of microcolins $A(13)$ and the 10-deoxy analogue, microcolin B (24). Microcolin A and, to a lesser extent, B proved to be potent in vitro immunosuppressive agents with $\mathrm{EC}_{50}$ values of 0.02 and $20.5 \mathrm{M}$ (cyclosporine $\mathrm{A} 17.8 \mathrm{nM}$ ) in the murine MLR assay. Semisynthetic preparation of microcolin $A$ analogues and subsequent testing of immunosuppressive potency revealed that a free hydroxy group at $\mathrm{C}-10$ and an intact pyrrolinone moiety are essential features of potently active agents. More detailed in vitro assays suggest that microcolin A does not affect interleukin-2 (IL-2) production or IL-2 receptor expression. In vivo experiments with $1.0 \mathrm{mg} / \mathrm{kg}$ suppressed the splenomegaly response, concentrations of $5.0 \mathrm{mg} / \mathrm{kg}$ resulted in death of the animals, and at doses lower than $1.0 \mathrm{mg} / \mathrm{kg}$, no suppression could be observed $(3,25)$. 


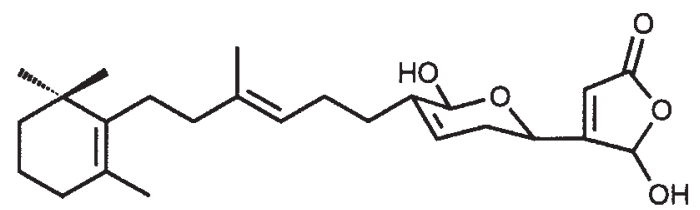

1 Manoalide
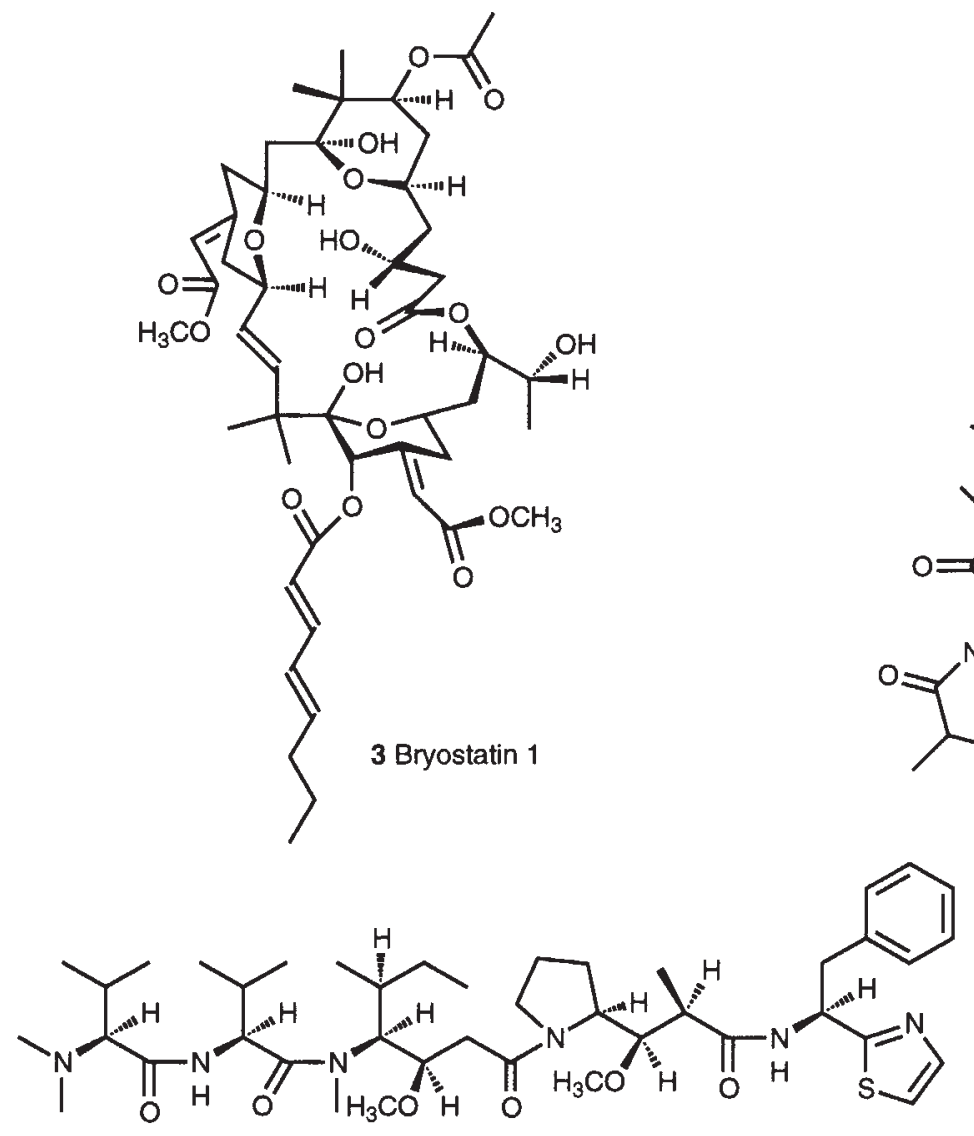

5 Dolastatin 10<smiles>C=C(Cl)[C@@](Cl)(CBr)CC[C@@H](Br)C(C)(C)Cl</smiles>

7 Halomon<smiles>CC(C)=CC1C[C@@H](C)[C@@H]2CC[C@H](C)c3c(O)c(OC4OC(C)C(O)C(O)C4O)c(C)c1c32</smiles>

2 Pseudopterosin E

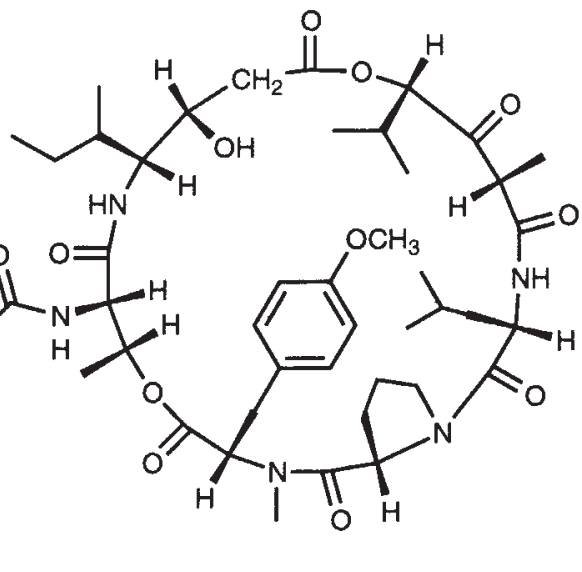

4 Didemnin B

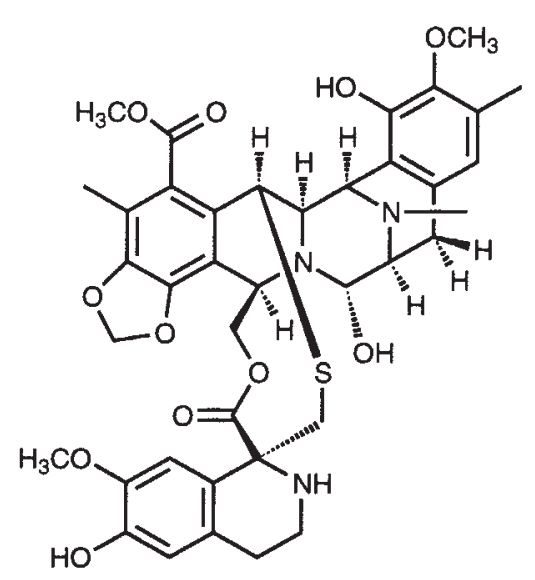

6 Ecteinascidin 743

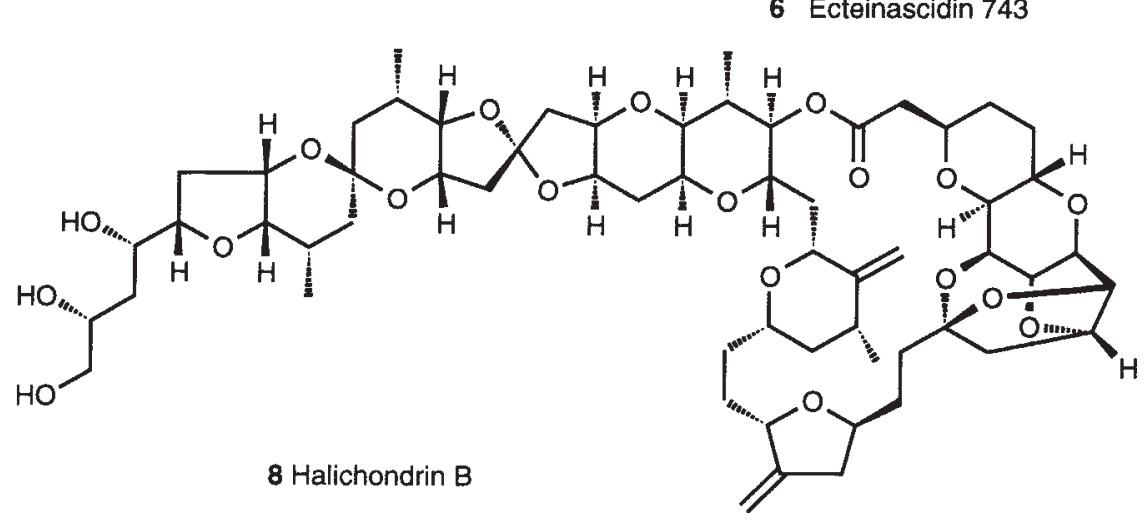


Didemnins isolated from the tunicate Trididemnum solidum (Didemnidae) show a remarkable array of biological activities, including immunosuppressive action. The recently reported didemnin $\mathrm{M}$ is strongly cytotoxic $\left(\mathrm{P} 388, \mathrm{IC}_{50} 2.0 \mathrm{ng} / \mathrm{ml}\right)$, but also shows potent immunosuppressive activity in the in vitro MLR assay and the in vivo graft-versus-host reaction assay (26).

\section{Mechanism-based bioassays in marine natural products studies}

Currently there is much interest for mechanism-based bioassays to augment or replace whole-cell and animal models as primary screens in drug discovery investigations (27). The combination of marine natural products chemistry with these new screening methodologies, many of them based on new developments in molecular biology, is probably opening up new dimensions in drug discovery. A few examples will demonstrate the potential of marine natural products as lead compounds in mechanism based test systems.

Cholesteryl ester transfer protein (CETP), a protein available through recombinant techniques, appears to be a suitable target for ailments related to atherogenic lipoprotein profiles. Screening of sponge extracts revealed a CETP inhibitory activity for the lipophilic extract of Xestospongia cf. wiedenmayeri (Petrosiidae). Bioassay guided fractionation yielded the isomeric compounds wiedendiol $\mathrm{A}(\mathbf{A})$ and $\mathrm{B}(\mathbf{1 5})$, which were both active in the CETP assay with an $\mathrm{IC}_{50}$ of $5 \mu \mathrm{M}(28)$.

In an attempt to find novel HIV-inhibitory compounds, 5000 extracts of marine and terrestrial organisms were screened in an ELISA based test-system detecting the binding of HIV gp120 to human CD4 receptor. The extract derived from the bright red Carbbean sponge Batzella sp., (Desmacidonidae) was found to inhibit gp120 CD4 binding. Batzelladines A (16) and B (17) were identified as the compounds responsible for this activity, and are the first low molecular weight molecules shown to inhibit this interaction. The activity, however, is not specific. Batzelladines also inhibit the binding of interleukin- 8 and of the calcitonin gene-related peptide to their respective receptors. They are also strongly cytotoxic (Vero cells $\mathrm{IC}_{50}=1.6$ and $1.8 \mu \mathrm{M}$, respectively), as well as inhibiting protein kinase $\mathrm{C}$ $\left(\mathrm{IC}_{50}=1.4\right.$ and $1.5 \mu \mathrm{M}$, respectively (29).

Relevant to the discovery of fertility regulation, a cotransfection assay in which cells are transiently transfected with plasmids encoding for the human progesterone receptor B1 and the respective reporter genes was employed to screen for selective progesterone agonists and antagonists. Two diastereomeric metabolites from the marine green alga Cymopolia barbata (Dasycladaceae) were found to interact with the human progesterone receptor. Interestingly, compound $\mathbf{1 8}$, (3R)-cyclocymopol monomethyl ether, had an antagonist activity with this receptor, while the epimer, (3S)-cyclocymopol monomethyl ether, was an agonist. Both compounds, most importantly, did not interact with human glucocorticoid receptors, the cause of many side effects for clinically used progesterone-antagonists, but interacted with the human androgen receptor. Compounds 18 and (3S)-cyclocymopol monomethyl ether are the first nonsteroidal progesteronereceptor modulators (30).

\section{Chemical Diversity within Species}

Secondary metabolite production is usually thought of as a characteristic and unique feature of a distinct species. Chemical investigations into the natural products profiles of marine organisms show, however, that the picture is much more complex. Many studies suggest that there is a great deal of variation, yielding an intriguing variety of structures from just one organism. Biosynthesis of secondary metabolites may be influenced by various external factors such as prevailing environmental conditions, e.g., presence of predators, infection with parasites, water temperature, depth, and nutrient levels. Internal factors, e.g., stage of development/reproduction and chemical races may also play a role. For marine macroorganisms the occurrence and type of symbionts within or on the tissue of the host animal may be of major importance, as may be the storage or further modification of secondary metabolites obtained from food sources, e.g., in sea hares and nudibranchs (31). Due to these changing parameters the chemical content of marine species often varies depending on where and when an organism is collected.

A good example of this phenomenon is the red algal family Plocamiaceae e.g., Plocamium cartilagineum (Plocamiaceae). This alga can be found in many locations ranging from Antarctica to tropical waters. Numerous chemical studies of this species show the presence of halogenated monoterpenes, e.g., 19-21, whose structure and yield vary greatly $(32,33)$. Even individuals from the same location differ in their secondary metabolite content (34). Another study this time of P. hamatum from different locations at the Great Barrier Reef yielded compounds $\mathbf{2 2 - 2 4}$ for a sample from Potter Reef, while the same species from Orpheus Island contained a single cyclic monoterpene, tetrachloromertensene (25) (35). Studies on the latter sample showed that there is considerable seasonal variation. It seems that the tetrachloromertensene (25) concentration gradually increases throughout the year up to August, September, October and then rapidly declines in October, November, December until the cycle begins again. This cycle was not linked to the reproductive cycle or any other obvious change in the environment of the plants (36). Subsequent studies revealed that tetrachloromertensene (25) is the cause of tissue necrosis observed on neighbouring Sinularia sp., (Alcyoniidae) which is competing with the alga for space on the reef. Thus, it was clearly shown that this metabolite is part of the survival strategy of the alga (37).

Chemical variation as a result of the ecology of an organism has been implied for the green alga Halimeda opuntia (Udoteaceae) from Pohnpei and Pago Bay, Guam. Of the two antifeedant metabolites, halimedatrial (26) and halimedatetraacetate (27), the former has proven more effective towards herbivorous fish. Subsequent studies revealed that populations of Halimeda from areas with a high herbivory pressure, usually reef slopes, had halimedatrial as their major metabolite, whereas plants from the reef top accumulated halimedatetraacetate (38).

One of the most intriguing examples of chemical variation within a single species is the sponge Dysidea herbacea (Dysideidae). More than 30 reports, since 1969, have been published on the secondary metabolites found in this species. Samples investigated have been obtained from different regions of the Great Barrier Reef, Australia, Papua New Guinea, the Red Sea, the Pacific Ocean, Palau, Pohnpei, Thailand, Fiji, and 
<smiles>CN(C)CCc1c2c3c(c4ccccc4nc3c3scnc13)C=CN2C</smiles><smiles>COc1ccc(O)c(CC2=C(C)CCC3C(C)(C)CCCC23C)c1O</smiles><smiles>COc1ccc(O)c(O)c1/C=C1\C(C)CCC2C(C)(C)CCC[C@]12C</smiles>

15 Wiedendiol B
11 Kahalalide F

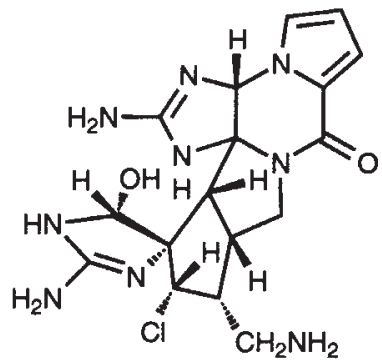

10 Palau'amine

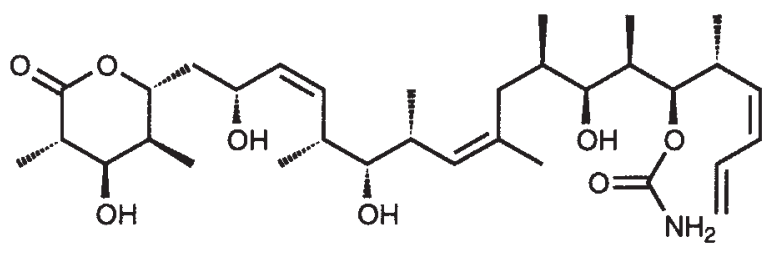

12 Discodermolide<smiles>CCC(C)C(NC(=O)C(NC)C(C)OC(=O)C(NC(=O)C(C)C)C(C)C)C(=O)NC</smiles>

$\prod_{0}$

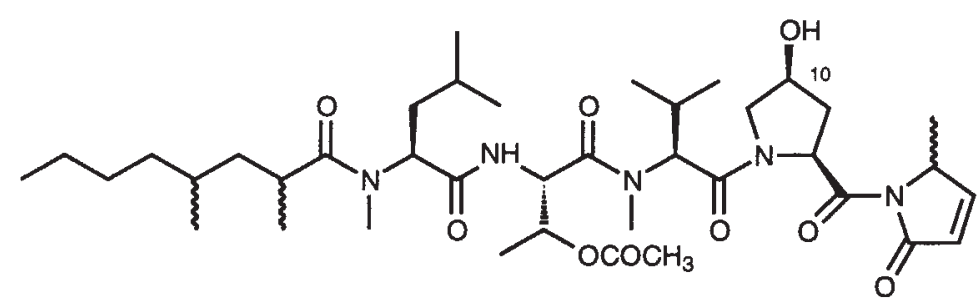

13 Microcolin A

14 Wiedendiol A

14 Wiedendiol A

$$
\text { (1) }
$$

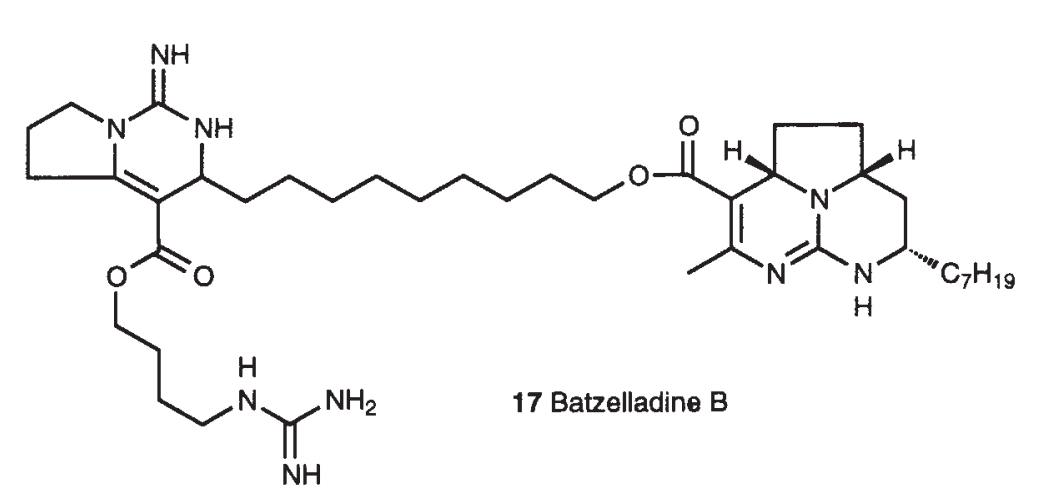
17 Batzelladine B 
the Indian Ocean. The gross morphology of this sponge varies greatly and ranges from thin tubular, massive flat, cup-shaped (39) to encrusting (40). The colour has been described as tan (Thailand) (39), light purple (Fiji), blue to blue-grey (Pohnpei) (40), and green to ochre (Australia). These changes are possibly due to different types of symbionts, i.e., cyanobacteria and/or bacteria, in the sponge's tissue.

Three types of secondary metabolites have been obtained from this species: brominated biphenyl ethers, peptides, and terpenes. The first investigation into the chemical profile of this sponge, collected in the Western Caroline Islands (Pacific Ocean), focused on compounds which had antimicrobial activity, resulting in the isolation of a penta- (28) and a dibromodiphenyl ether (29) (41). Subsequently, this type of metabolite was also obained from samples collected from Palau (42), the Great Barrier Reef (Cooktown), and Fiji (43). More than ten of these compounds are described from this source organism, with structures varying in their oxygenation pattern and halogen content (44). To date, no such metabolites have been reported from samples collected in the Red Sea and the Indian Ocean.

The second major group of natural products from this one sponge species is derived from amino acids. A sample from Cooktown, Australia, contained, in addition to the previously mentioned biphenyl ethers, dysidenin (30), a polychlorinated and thiazole-containing metabolite (45). Another sample, this time collected from the Great Barrier Reef off Townsville, contained no aromatics but the pyrrolinone derivative, dysidin (31) in high yield (1-1.2\%) (46). Samples from the Gladstone area of Queensland (Southern Great Barrier Reef), Australia, were the source of another polychloroamino acid derivative, a diketopiperazine (32) which was present at $1.2 \%$ (47). Yet a further sample from the Great Barrier Reef, whose location was not specified, gave the acyclic compound, herbaceamide (33) (48). Sponge collections from reefs of Papua New Guinea contained isodysidenin (34) (49) and herbamide A (35) (50). Different isodysidenin derivatives were also found in samples from the Bowen region (Central Great Berrier Reef) (51). Investigations of samples from Pohnpei and Palau by the Faulkner group (40), and of Red Sea samples by Kashman and his colleagues $(52,53)$ showed them all to contain dysidenin and dysidin type metabolites but with further variations on the basic structure (36-39). All these compounds share a unique trichloromethyl function, not yet encountered anywhere else in nature, with the exception of the recently reported barbamide (40) from the marine blue-green alga Lyngbya majuscula (Oscillatoriaceae) (54).

The terpenoid metabolites reported from $D$. herbacea are predominantly sesquiterpenes. They possess a spiro moiety as in herbadysidolide (41), herbasolide (42) (55), and spirodysin (43) (56), this type of compound being isolated to date exclusively from samples of Australian and Papua New Guinean origin, or they are furanosesquiterpenes such as furodysinin $(\mathbf{4 4 , 4 5})(57$, 58). A series of furanosesquiterepenes was found in samples from Fiji, which showed interesting differences in chirality when compared to compounds from Great Barrier Reef samples. Sponges from Australia seem to produce the optical antipodes [(+)-furodysinin] (45) to those of samples from Fiji [(-)-furodysinin] (44) (39). Recently, however, D. herbacea from two collection sites on the Great Barrier Reef less than $120 \mathrm{~km}$ apart also yielded enantiomeric furanosesquiterpenes
(59). These results suggest that samples of this sponge species differ in their enzymatic capabilities concerning the cyclization of geranyl-geranyl-pyrophosphate.

A sample of $D$. herbacea from the Red Sea, Gulf of Suez, is unique in that it contains sesterterpenes with a scalarin skeleton, e.g., scalardysin $A(46)(60)$ and the $C_{21}$-furanoterpene furospongolide (47) (61).

With the exception of one report (45), it seems that sponges which do not contain brominated phenyl ethers accumulate amino acid derivatives and vice versa. Since these compounds are structurally related to blue-green algal metabolites $(62,63$, $160)$, it has been suggested that they might derive from the algal symbiont and not the animal itself. This was recently proven for a sample from the GBR and Palau (see below, Symbiosis) $(62,63)$. Terpenes seem to co-occur with the chlorinated peptides but not with the brominated phenyl ethers, and are located in the sponge cells.

Dysidea herbacea is a sponge species which has yielded new metabolites for more than 20 years, and no doubt further collections from different locations will continue to reveal new chemistry.

Australian researchers investigated the diterpene content of the sponge Rhopaloeides odorabile (Spongiidae) from various habitats. Species from a range of different locations, but from an equal depth $(10 \mathrm{~m})$ did not differ significantly in diterpene composition. Experimentally induced change in environmental parameters through transplanting genetically identical fragments of the sponge to different depths under either shaded or illuminated conditions resulted in variations according to treatment. Shallow-water and illuminated specimens showed a significantly higher diterpene content than the shaded ones. The composition of the diterpene mixture was dependent on the overall diterpene content. At concentrations of less than $1.2 \%$ of total diterpenes only alcohols, e.g. , 48, were present, above that concentration the equivalent peracetates, e.g., 49, also accumulated. The study suggests that in the case of this sponge, variation occurs not through genetic differences but is a function of environmental conditions, e.g., light-induced stimulation of diterpene production (64).

In a similar manner the diterpene metabolites of Myrmekioderma styx (Halichondriidae) collected from various depths were compared. Shallow-water samples of this sponge contained simple acyclic diterpenes, while samples collected between 33 and $66 \mathrm{~m}$ depth contained mostly tricyclic diterpenes, and those below $66 \mathrm{~m}$ had predominantly bicyclic diterpenes. Again, as in the case above, secondary metabolite content was related to depth. In order to prove this contention unambiguously, however, reciprocal transplant experiments are necessary (65).

The investigation of small samples of the Mediterranean sponge Raspaciona aculeata (Raspailiidae) collected off Blanes during January to March 1992 revealed, for all but one sample, the typical presence of raspacionins, e.g., 50, triterpenoids containing two perhydrobenzoxepine systems. The one exception, even though morphologically undistinguishable from the other sponges, contained a new labdane furanoditerpenoid, blanesin (51). This is quite an unusual case since the same species from 
<smiles>C=C(/C=C/C(Cl)C(C)(Cl)/C=C/Br)CCl</smiles>

19<smiles>C[C@](Cl)([C@H](Br)/C=C/[C@@](C)(Cl)CBr)[C@H](Br)CCl</smiles>

22<smiles>C[C@]1(Br)C[C@H](Br)[C@H](/C=C/Cl)C[C@H]1Cl</smiles>

20<smiles>C=C[C@](C)(Cl)C(Br)/C=C/[C@@](C)(Cl)CBr</smiles><smiles>C[C@]1(/C=C/Cl)C[C@@](Cl)(CBr)[C@@H](Cl)C[C@@H]1Cl</smiles>

21<smiles>C=C1C[C@](C)(/C=C/Cl)[C@H](Br)C[C@@H]1Cl</smiles>

24<smiles>C[C@@]1(Cl)C[C@](C)(/C=C/Cl)[C@H](Cl)C[C@@H]1Cl</smiles>

25<smiles>Oc1cc(Br)c(Br)c(Br)c1Oc1ccc(Br)cc1Br</smiles>

28<smiles></smiles>

31 Dysidin<smiles>C[C@H](NC(=O)[C@H](CC(C)(C)C)N(C)C(=O)C[C@@H](C)C(C)(C)C)c1nccs1</smiles>

34 Isodysidenin<smiles>C[C@H](CC(=O)N(C)[C@H](CC(C)(Cl)Cl)c1nccs1)C(Cl)(Cl)Cl</smiles><smiles>C[C@H](NC(=O)[C@H](CC(C)(C)C)N(C)C(=O)C[C@@H](C)C(Cl)(Cl)Cl)c1nccs1</smiles><smiles>CC(C)CC1C(=O)N(C)/C(=C/C(C)C(Cl)(Cl)Cl)C(=O)N1C</smiles>

32<smiles>COC(=O)[C@H](C[C@@H](C)C(C)(C)C)N(C)C(=O)/C=C/CC(C)C(Cl)(Cl)Cl</smiles>

33 Herbaceamide<smiles>C[C@H](CC(=O)N[C@H](C[C@@H](C)C(Cl)(Cl)Cl)c1nccs1)C(Cl)(Cl)Cl</smiles>

36<smiles>C[C@H](CC(=O)N(C)[C@H](C[C@@H](C)C(Cl)(Cl)Cl)c1nccs1)C(Cl)Cl</smiles> 
<smiles>COC(=CCN(C)C(Cc1ccccc1)c1nccs1)CC(C)C(F)(F)Cl</smiles>

40 Barbamide<smiles>CC1=C[C@H]2C[C@@]3(CCOC3=O)[C@@H](C)[C@@H]2CC1</smiles>

41 Herbadysidolide<smiles>CC(=O)CC[C@H]1C(=O)C[C@]2(CCOC2=O)C1(C)C</smiles>

42 Herbasolide<smiles></smiles>

43 Spirodysin<smiles>CC1=CC2Cc3occc3C(C)(C)C2CC1</smiles>

$446 R, 11 R$ $456 S, 11 S$

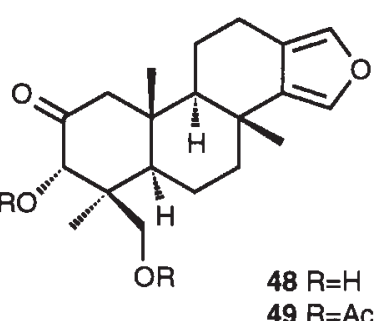

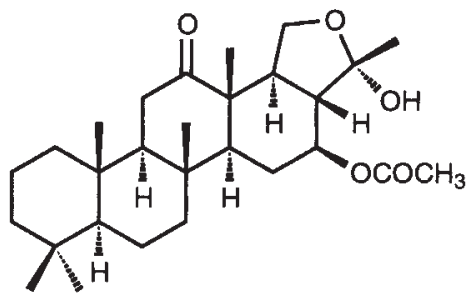

46 Scalardysin A

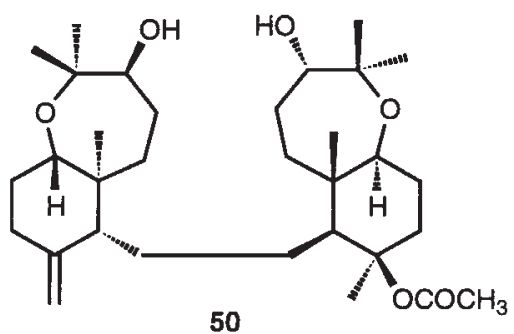<smiles>CC1=CC[C@@H]2C(C)(C)[C@H](O)C(=O)C[C@@]2(C)[C@@H]1CCc1ccoc1</smiles>

51 Blanesin<smiles>C/C=C/C=C/C=C/C(=O)N[C@H](CC(=O)N[C@H](C(=O)[C@H]1C(=O)NC(=O)[C@H]1C)C(C)C)c1ccccc1</smiles>

52 Andrimid

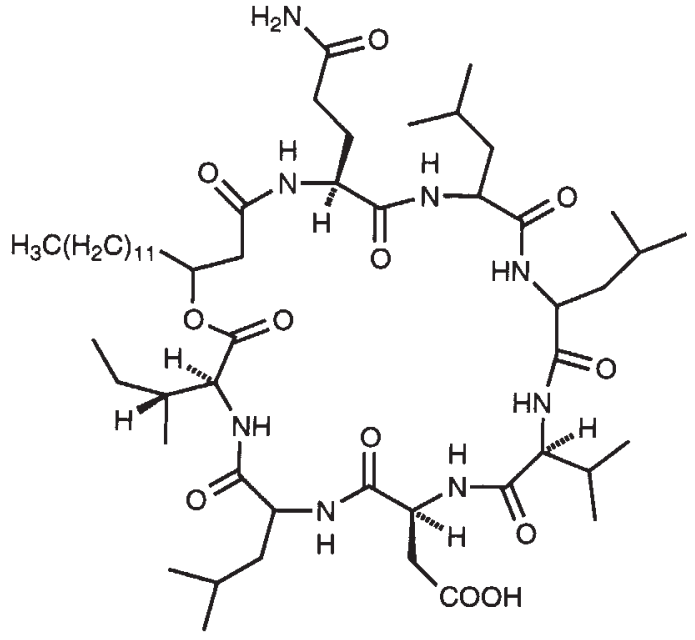

54 Halobacillin<smiles></smiles>

53 Moiramide B

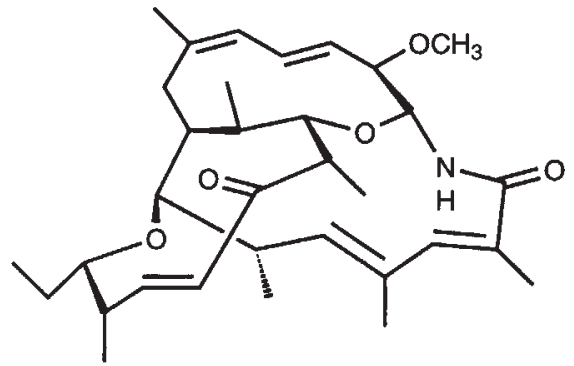

55 Halichomycin<smiles>CN1C(=O)C23CC4=CC=CC(O)C4N2C(=O)C1(CO)S3</smiles><smiles>CS[C@@]1(CO)C(=O)N(C)[C@](CO)(SC)C(=O)N1Cc1ccccc1</smiles> 
the same habitat yielded a completely unrelated metabolite to those of surrounding sponges (66).

It is thus evident that there can be many more new secondary metabolites expected from marine plant and animal species that have already been investigated. In many cases the taxonomy of species needs closer examination with respect to species homogeneity. Dysidea herbacea (Dysideidae) for example, has to be compared to other Dysidea and related species, e.g., Phyllospongia species (Spongiidae). Even more fascinating however, would be to study which factors control the biosynthesis of the various compounds, and what their function might be. Ongoing studies on Delisea pulchra (Bonnemaisoniaceae), involving investigation of chemical variation, function of secondary metabolites in the ecosystem, and the applied aspect of antifouling issues (67) exemplify such a comprehensive investigation.

\section{New Source Organisms: Marine Micro-organisms}

The level of interest in marine micro-organisms has been slowly increasing over the last years, with particular emphasis being placed on the investigation of pharmacologically active compounds (for reviews, see references 68-70) and those with toxicological significance, e.g., tetrodotoxin and saxitoxin (71). Research in marine microbiology is hampered by the level of knowledge concerning the basic biology and culture techniques for marine-derived organisms, and many more biological and ecological investigations are needed as a pre-requisite for the full exploration of the biochemical potential of these organisms. Consequently, reports concerning investigations of marine bacteria have concentrated mainly on organisms growing in nutrient-rich broths, e.g., actinomycetes (72-75). Although current molecular biology techniques allow the study of essentially all members of the marine microbiological community, it is not possible for natural products researchers, at present, to generate sufficient biomass to enable successful chemical investigations of all of these organisms. According to Fenical (76), less than $1 \%$ of the micro-organisms in a sample will form colonies with the usually applied isolation techniques (77). Thus, vast areas of the marine bacterial community lie unexplored, at least in the chemical sense. Some of the more interesting and recently reported metabolites from marinederived bacteria are peptide-type structures and macrolides. In an attempt to find agents against antibiotic-resistant pathogens, the bacterium Pseudomonas fluorescens (Pseudomonadaceae) isolated from a tunicate, was found to have potent antibacterial activity. This activity was only observed when cultures were grown on solid media in contrast to liquid shake cultures. The active principles were determined as andrimid (52), formerly obtained from an Enterobacter sp., (Enterobacteriaceae) and the related, and novel, moiramide $B$ (53) (78). Deep-sea sediments hold further promise concerning interesting micro-organisms. A Bacillus species (Bacillaceae), taken from a $124 \mathrm{~m}$ deep sediment core, yielded a new cyclic acylpeptide of the iturin class, halobacillin (54), which has moderate cytotoxic properties (79). A structurally unique metabolite from the bacterium Streptomyces hygroscopicus, isolated from the gut of a fish, is halichomycin (55), a tricyclic macrolide with cytotoxic potential (80). Further development in this area will most probably depend on consequent research into the more difficult or as yet uncultured marine bacteria and the optimisation of culture conditions.
To date very little research has been performed on the chemistry of marine-derived fungi $(68,81-83)$. In the $1940 \mathrm{~s}$, the fungus Cephalosporium sp., (Fungi imperfecti) was isolated from the microbial flora of sea water collected from Cagliari, Italy. Subsequent chemical and biological investigation of this fungi led to the discovery of the cephalosporins, now widely used in antibiotic therapy (84).

Further reports in the area of marine fungal chemistry have appeared essentially only from 1977 onwards, with the description of less than 10 metabolites in the ten years following (see Table 1). Gliotoxin (56) (85), the related gliovictin (57) (86), and the sesquiterpenes culmorin $(58)(87,88)$ and siccayne (59) (89) were found. In Corollospora pulchella (Halosphaeriaceae) the known antibiotics melinacidin III (60) and IV (61) and gancidin W (62) were identified (90), while from Zopfiella marina (Sordariaceae) zopfinol (63) (91) was the sole isolate. Leptosphaerin $(\mathbf{6 4})(92,93)$ was described from the lignicolous fungi Leptosphaeria oraemaris (Pleosporaceae). All these compounds were structurally similar or identical to ones known from terrestrial sources. For some of them antimicrobial properties were found. It was not until 1989 that another promising bioactive compound from a marine fungus was reported. Gloer and his colleagues isolated $L$. obiones, an ascomycete, from the surface of a salt marsh grass and obtained obionin A (65), which interacts with the central nervous system by binding to the dopamine receptor (94).

A further study of L. oraemaris, undertaken by the group of Pietra, yielded none of the previously found metabolites, but the polyketides, leptosphaerolide (66) and its o-dihydroquinone derivative (67) (95). Eremophilanes and trinor-eremophilanes (68-74) were obtained from the marine deuteromycete Dendryphiella salina (Fungi imperfecti), which resemble the eremophilanes from terrestrial fungi $(96,97)$. Several other compounds were structurally characterised (see Table 1), but did not exhibit striking activity and were derived mainly from fungi isolated from mangrove swamps, e.g., the lactones helicascolides A (75) and B (76) and ochracin (77) (98), and the depsidones auranticins A (78) and B (79). Stachybotrins A (80) and B (81) (99) were isolated from a brackish water fungus and shown to exhibit antimicrobial activity (100).

Marine macroalgae are hosts for marine fungi (101). Microbiological investigation of the alga Enteromorpha intestinalis (Ulvaceae) yielded a strain of a Penicillium sp., (Fungi imperfecti) which produced the moderately cytotoxic alkaloids communesins A (82) and B (83) (102). From the marine macroalgae Sargassum tortillae (Sargassaceae) a species of Leptosphaeria (Pleosporaceae) was isolated. When cultured this fungal species produced the epipolysulfanyldioxopiperazines, leptosins $A, G$, $G_{1}, G_{2}$, and $H(84-93)$. These metabolites all resemble gliotoxin (56), a sulphur-containing diketopiperazine first isolated from a terrestrial fungus. Leptosins show favourable in vitro cytotoxic activity with $\mathrm{IC}_{50}$ values towards P-388 cells in the range of $1.75 \times 10^{-3}$ to $8.6 \times 10^{-2} \mu \mathrm{g} / \mathrm{ml}$. The antitumour activity of the most active leptosins, $A$ and $C$, was established using Sarcoma-180 ascites tumour cells implanted into mice $(103,104)$.

Japanese workers have adopted the approach of isolating fungi from the intestines of marine animals, e.g., fish. From this source a few moderately cytotoxic compounds are described, fellutamides A (94) and B (95) which are peptides produced by Penicillium fellutanum (Fungi imperfecti) (110), and fumiquin- 


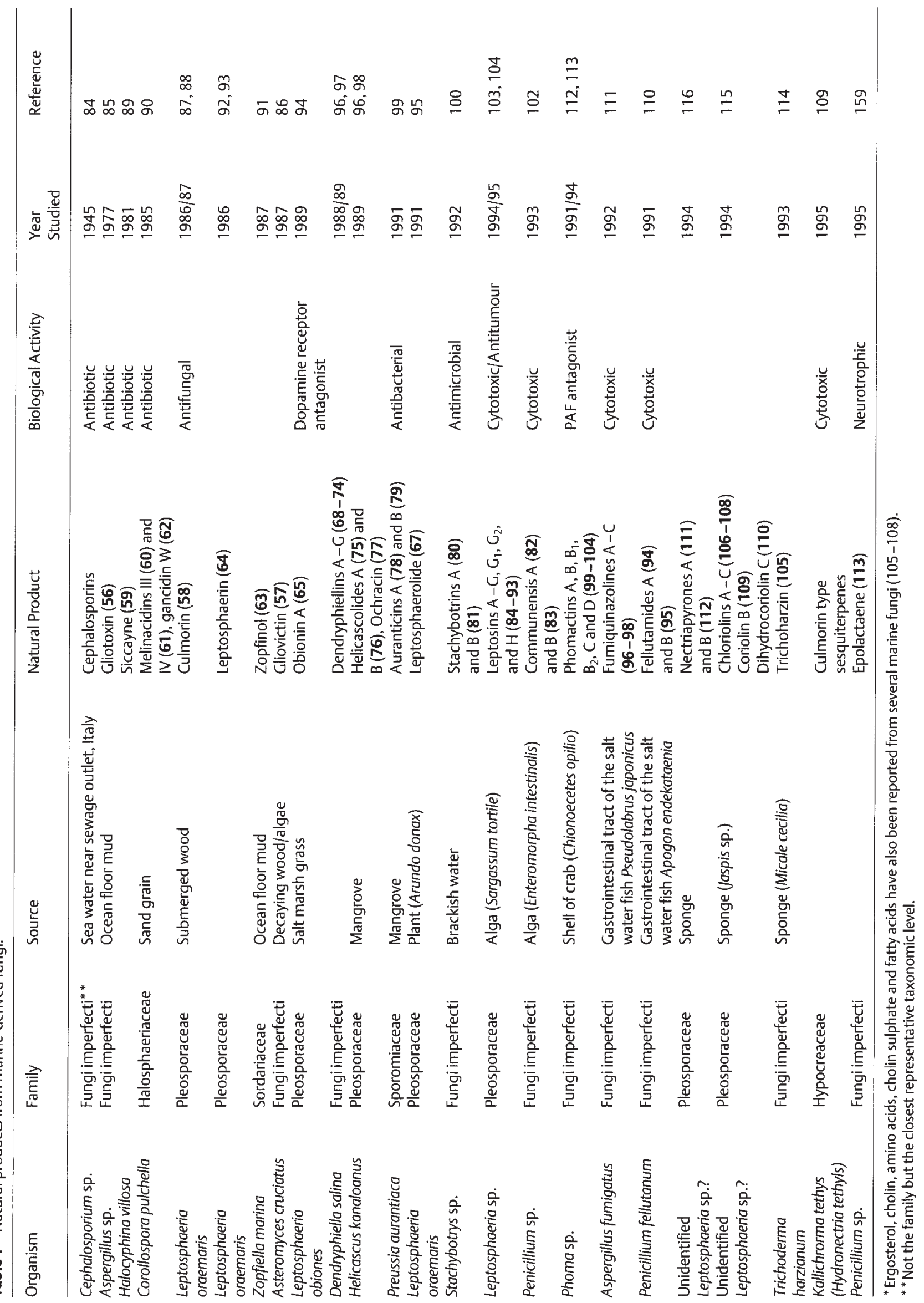


<smiles>CC1(C)CCCC2(C)C(O)C1C1C2C(O)CC1(C)C</smiles>

58 Cuimorin<smiles>C=C(C)C#Cc1cc(O)ccc1O</smiles>

59 Siccayne<smiles>CCCCC/C=C/C(O)C(O)/C=C/c1ccc(Cl)c(O)c1CO</smiles>

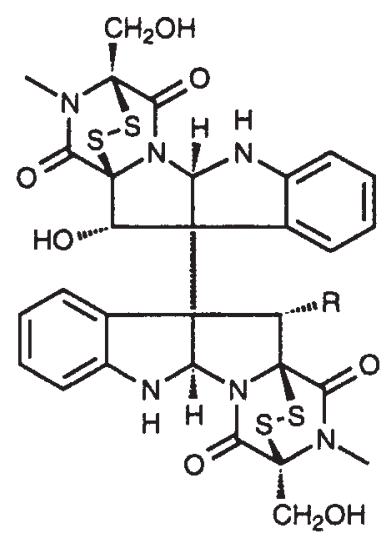

60 Melinacidin III $\mathrm{R}=\mathrm{H}$ 61 Melinacidin IV $\mathrm{R}=\mathrm{OH}$<smiles>CC(C)CC1NC(=O)C2CCCN2C1=O</smiles>

62 Gancidin<smiles>CC(=O)NC1=C[C@H]([C@@H](O)CO)OC1=O</smiles>

64 Leptosphaerin<smiles>CCC(C)/C=C(\C)C1=Cc2cc3cc(OC)c(=O)oc3c(O)c2CO1</smiles>

66 Leptosphaerolide<smiles>[R7]C(/C=C/C=C/C(=O)O[C@H]1C=CC2=CC(=O)[C@@H](O)C[C@]2(C)[C@H]1C)(C[B])CC[B]</smiles>

68 Dendryphiellin A $R_{1}=R_{2}=H, R_{3}=O H$

69 Dendryphiellin $B \quad R_{1}=R_{3}=H, R_{2}=O H$

70 Dendryphiellin C $R_{1}=R_{2}=R_{3}=H_{1}$ (6S)

71 Dendryphiellin D $R_{2}=R_{3}=H, R_{1}=O H$<smiles>C=C1CO[C@]2(OCC)C=C3C=C[C@H](OC(=O)/C=C/C=C/[C@H](C)CC)[C@H](C)[C@]3(C)C[C@]12O</smiles>

73 Dendryphiellin F<smiles>[R]c1c(O)cc(/C(C)=C/C(=O)O)c2c1Oc1c(/C(C)=C/C)cc(OC)c(C)c1OC2=O</smiles>

77 Ochracin<smiles>C[C@H]1Cc2cccc(O)c2C(=O)O1</smiles>

75 Halicascolide $\mathrm{A} \quad \mathrm{R}=\alpha-\mathrm{OH}$ 76 Halicascolide $B \quad R=\beta-O H$
78 Auranticin A $\mathrm{R}=\mathrm{CH}_{2} \mathrm{OH}$

79 Auranticin $\mathrm{B} \quad \mathrm{R}=\mathrm{CHO}$ 
azolines A (96), B (97), and C (98) from Aspergillus fumigatus (Fungi imperfecti) (111). Marine invertebrates are also becoming a useful source for the isolation of microbes. Phomactins $A$, B, B1, B2, C, and D (99-104), tetra- and bicyclic diterpenes distinguished by their strong platelet aggregating factor (PAF) antagonistic activity, can be obtained from a fungus identified as Phoma sp., (Fungi imperfecti) which occurs in the shell of the crab Chinoecetes opilio (Maiidae) $(112,113)$. Three studies dealing with the isolation of fungi from sponge tissue and their subsequent cultivation and chemical analysis are reported. The imperfect fungus Trichoderma harzianum (Fungi imperfecti) was isolated from the marine sponge Micale cecilia (Mycalidae) and yielded the polyketide metabolite trichoharzin (105) upon cultivation in salty medium. Since T. harzianum is a common soil fungus it also grows in fresh water medium but does not produce any trichoharzin (114). An unidentified fungal strain was obtained from the sponge Jaspis aff. johnstoni (Jaspidae). Upon cultivation in marine medium it produced five sesquiterpenes, all highly functionalised with epoxy, chloro, hydroxy, and carbonyl functionalities, called chloriolins A-C (106-108), coriolin B (109), and dihydrocoriolin C (110) (115). Two of these compounds (109 and 110), one of which (109) has moderate cytotoxic properties, were known from the terrestrial wood rotting fungus Coriolus consors [Trametes consors (Polyporaeae)]. Nectriapyrones A (111) and B (112) are also typical fungal metabolites and some new derivatives of this structural class were found in the saltwater culture of the fungi isolated from the sponge Stylotella sp., (Hymeniacidonidae) (116). Even though the reported structures are interesting there is to date no unique chemistry from marine-derived fungi.

In most of these studies it is not clear whether the micro-organisms investigated are truly marine and whether they are epibionts, symbionts, pathogens, or merely accidentally present in or on the studied materials. In some cases it appears that terrestrial fungi were isolated, which, as some investigations have shown $(117,118)$ are present in the oceans and represent a major problem when trying to obtain the reportedly slow-growing marine fungi. Considering these observations it is evident that progress in obtaining more specialised marine fungi may yield more diverse and novel chemistry and biological activity.

The final group of marine-derived micro-organisms to be discussed here are marine cyanobacteria, also a relatively poorly investigated group of organisms. The majority of secondary metabolites derive from samples with sufficient biomass to enable field collection of samples e.g., Lyngbya species (Oscillatoriaceae). The interest in $L$. majuscula was first spurred by its ability to induce a dermatitis-like condition in swimmers ("swimmers itch"), which was traced back to the potently inflammatory and tumour-promoting compound lyngbyatoxin A (119). L. majuscula is also the source of the recently discovered immunosuppressive microcolins A (13) and B described in detail above, and the antimitotic curacin $A(114)$. Curacin $A$ is a thiazole ring-containing lipid which inhibits cell growth in the lower $\mathrm{ng} / \mathrm{ml}$ range by inhibiting tubulin polymerisation in a way similar to colchicine (120-122).

Moore's group in Hawaii investigated marine and terrestrial strains of Nostoc linckia (Nostocaceae) and found completely different types of natural products responsible for the cytotoxic activity of the extracts. The marine strain produced borophycin
(115), a most unusual boric acid complex consisting of a polyketide-based structure, which resembles the ionophoric antibiotic boromycin, and aplasmomycin. This compound has pronounced cytotoxicity towards KB (human epidermoid carcinoma) cells $\left(\mathrm{IC}_{50}=20 \mathrm{ng} / \mathrm{ml}\right)$ and LoVo (human colcorectal adenocarcinoma) cells $\left(\mathrm{IC}_{50}=7.5 \mathrm{ng} / \mathrm{ml}\right)(123)$.

Hormothamnion enteromorphoides (Microchaetaceae), in contrast to Nostoc linckia, is a cyanophyte which occurs solely in the marine environment. This organism was found to contain the potent cytotoxin ( $\mathrm{IC}_{50}=530 \mathrm{ng} / \mathrm{ml}$, KB cells) hormothamnione (116), a yellow pigment based on a styrylchromone skeleton (124). The same cyanophyte also produces cytotoxic cyclic peptides composed of six common and five new amino acids. One of these, hormothamnin $A$ is a stereoisomer of laxaphycin A, isolated from the terrestrial blue-green alga Anabaena laxa (Nostocaceae) $(125,126)$.

The true biochemical potential of marine cyanophytes is as yet to be realised, and many new and interesting compounds possessing biological activity can be expected to emerge from these source organisms in the not too distant future.

\section{Chemical Ecology of Marine Macro-Organisms and Associated Micro-Organisms}

\section{Symbiosis}

The majority of marine invertebrates represent symbiotic systems composed of the animal, e.g., sponge, and its symbiotic micro-organisms. Apart from the intriguing biological questions posed by these little investigated life forms (127), such marine micro-organisms may hold great biochemical potential.

For sponges it has been observed that their total biomass can consist of $40 \%$ or more of microbial tissue $(128,129)$. Microbes documented to be found in sponges are predominantly bacteria (122) and cyanobacteria (130), and to a lesser extent dinophycean zooxanthellae and eucaryotic algae (130). Even though fungi are sometimes mentioned in this context (131), there is no evidence in the literature to suggest this to be the case. Bacteria, e.g., Pseudomonas (Pseudomonadaceae) and Aeromonas (Vibrionaceae) species in Verongia (Verongiidae), may be present as free-living cells in the mesohyl of the sponge, and/or as intracellular symbionts $(129,132)$. Cyanobacteria, e.g. , of the Aphanocapsa (Microcystaceae) Phormidium (Phormidiaceae), or Oscillatoria spongeliae (Oscillatoriaceae) type, have been found in sponges of numerous genera. The majority of cyanobacteria detected in sponges seem to occur in the mesohyl, where they are free-living, others exist in large vacuoles within the sponge tissue, with only very few being found in digestive vacuoles (133-135). In clionid sponges zooxanthellae-type symbionts e.g., Gymnodinium microadriaticum (Gymnodiniaceae) in Cliona caribbaea (Clionidae), occur (123). In certain sponge species filamentous algae are found in intimate association with spongin fibres. In some Caribbean sponges these algae were identified as the chlorophyte Ostreobium cf. constrictum (Phyllosiphonaceae) and the rhodophyte Acrochaetium spongicolum (Acrochaetiaceae). Red macroalgae of the genus Jania (Corallinaceae) have been observed growing inside sponge tissue and have been found to constitute more than $60 \%$ of the sponge body. These calcareous algae supposedly serve as skeletal support for the host animal (130). 
<smiles>[R]C/C(=C\CC[C@@]1(C)Oc2c(c(O)cc3c2CNC3=O)C[C@@H]1O)CCC=C(C)C</smiles>

80 Stachybotrin $A \quad \mathrm{R}=\mathrm{OH}$ 81 Stachybotrin $B \quad \mathrm{R}=\mathrm{H}$

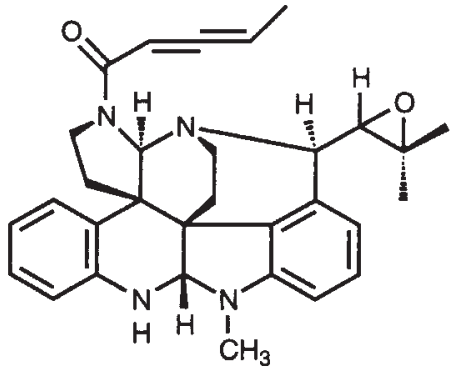

83 Communesin B

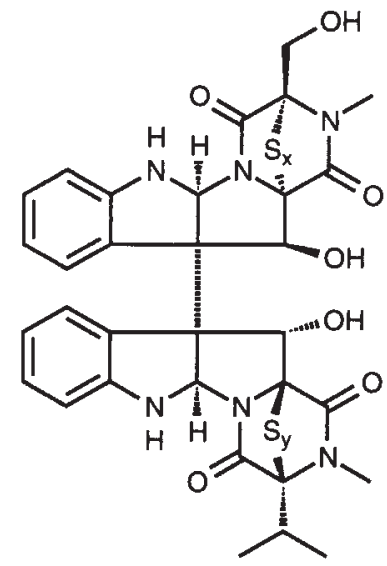

87 Leptosin $G \quad x=4, y=3$ 88 Leptosin $G_{1} \quad x=3, y=3$ 89 Leptosin $G_{2} \quad x=2, y=3$ 90 Leptosin $H \quad x=2, y=4$<smiles></smiles>

82 Communesin A
84 Leptosin A $x=4, y=2$ 85 Leptosin $B \quad x=3, y=2$ 86 Leptosin C $x=2, y=2$<smiles>[R]C1NC(=O)[C@@H](C[C@]2(O)c3ccccc3N3C(=O)[C@H](C)NC32)n2c1nc1ccccc1c2=O</smiles>

96 Fumiquinazoline A $\mathrm{R}=\beta-\mathrm{CH}_{3}$ 97 Fumiquinazoline $\mathrm{B} \quad \mathrm{R}=\alpha-\mathrm{CH}_{3}$

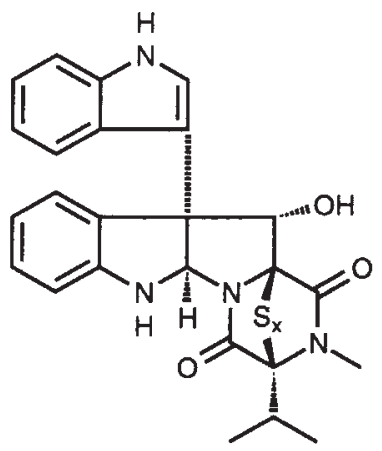

91 Leptosin $D \quad x=2$ 92 Leptosin $E \quad x=3$ 93 Leptosin F $x=4$

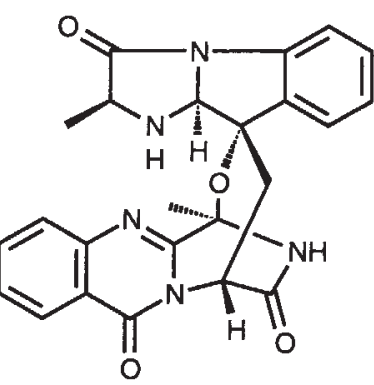

98 Fumiquinazoline
94 Fellutamide $A$ R=OH 95 Fellutamide $B \quad \mathrm{R}=\mathrm{H}$<smiles>CNC(C=O)CC(C)C</smiles>

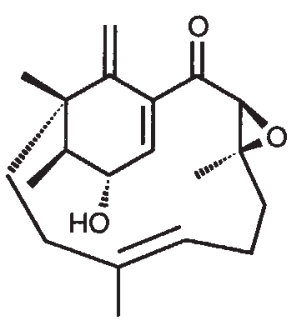

102 Phomactin B2<smiles>C/C1=C\CC[C@@]2(C)O[C@H]2C(C(=O)C2=CC[C@@H]3CCC=C2C3)[C@@H]1CO</smiles>

103 Phomactin C
100 Phomactin $B \quad \mathrm{R}_{1}=\mathrm{H}, \mathrm{R}_{2}=\mathrm{OH}$ 101 Phomactin B1 $\mathrm{R}_{1}=\mathrm{OH}, \mathrm{R}_{2}=\mathrm{H}$

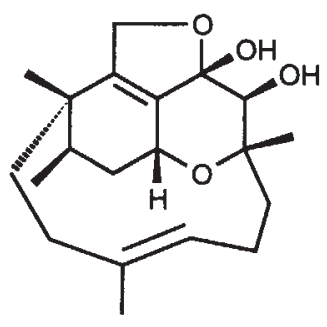

99 Phomactin A

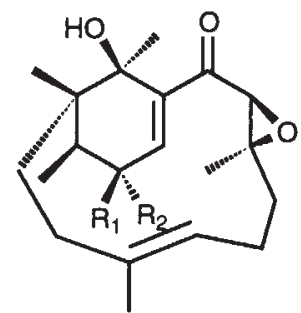




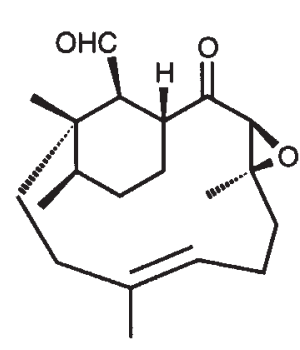

104 Phomactin D<smiles>[2H][C@@]1([C@@H](C)CC)C=C[C@H]2[C@@H](O)[C@@H](OC(=O)/C=C(\C)CC(=O)O)C[C@@H](C)[C@H]2[C@H]1C(=O)CCO</smiles>

105 Trichoharzin<smiles>CC1(C)C[C@H]2C=C(CO)[C@](C)(C(=O)CCl)[C@@H]2[C@@H]1O</smiles>

106 Chloriolin A<smiles>[R]C(CCCCCC)C(=O)O[C@@H]1[C@H]2[C@@H](CC1(C)C)[C@@H](O)C1=C(Cl)C(=O)[C@@](O)(CO)[C@]12C</smiles>

107 Chloriolin $\mathrm{B} \quad \mathrm{R}=\mathrm{OH}$ 108 Chloriolin $\mathrm{C} \quad \mathrm{R}=\mathrm{H}$<smiles>C/C=C(\C)c1cc(OC)cc(=O)o1</smiles>

111 Nectriapyrone $A$

112 Nectriapyrone B<smiles>C=CC[C@@H](CC/C(C)=C/C=C/CC/C=C/[C@@H]1CSC([C@H]2C[C@H]2C)=N1)OC</smiles>

114 Curacin A<smiles>COc1c(OC)c(O)c2c(=O)c(C)c(/C=C/c3cc(O)cc(O)c3)oc2c1OC</smiles>

116 Hormothamnione<smiles>CC1=CCC[C@H]2[C@@H](C)[C@](C)(Cc3cc(O)ccc3O)[C@H](C)CC[C@]12C</smiles>

117 Avarol

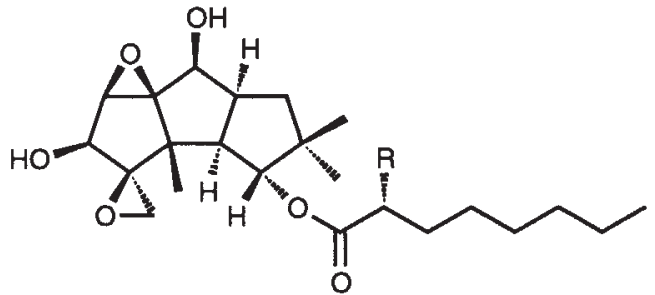

109 Coriolin $\mathrm{B} \mathrm{R}=\mathrm{H}$ 110 dihydrocoriolin $\mathrm{C} \mathrm{R}=\mathrm{OH}$<smiles>C/C=C(\C=C(C)/C=C/CC/C=C(\C)C(=O)C12OC1C(C)(O)NC2=O)C(=O)OC</smiles>

113 Epolactaene

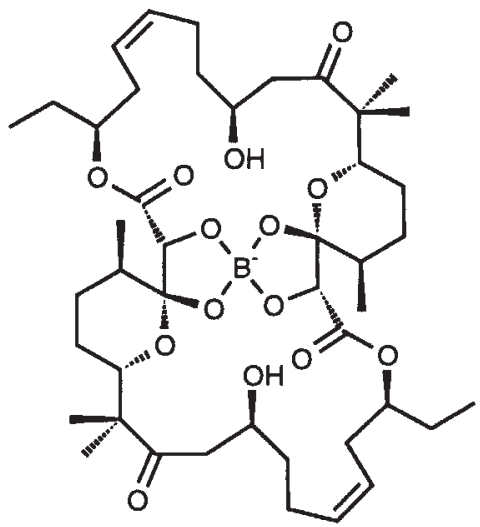

115 Borophycin<smiles>O=C1Nc2ccccc2C1=O</smiles>

118<smiles>OCCc1ccc(O)cc1</smiles> 
These associations clearly raise the questions: (i) How are such systems regulated? (ii) How does the sponge control the growth of (micro)organisms within its tissue? According to electron microscopic observations, microbial symbionts rarely seem to be digested by the sponge (134). It is as yet unclear as to how sponges distinguish between microbial symbionts and food. Some experimental data suggest the involvement of lectins in these recognition systems. Thus the marine bacterium Pseudomonas insolita (Pseudomonadaceae), which is the major bacterium in the sponge Halichondria panicea (Halichondriidae), only grows if a lectin isolated from the host organism is added to the culture medium (131). For the involvement of secondary metabolites no experimental data exist, but they may well play a role in such regulations. That sponge symbioses can escape the control of the host organism was demonstrated by Rützler in a case involving the sponge Geodia papyracea (Geodidae), whose tissue consists of up to $50 \%$ of a coccoid cyanobacterium. If conditions become too favourable for cyanobacterial growth considerable damage to the host sponge can be caused by their rapid reproduction (136).

Animals containing cyanobacteria tend to grow in well illuminated areas of the oceans, and typically not deeper than 15 meters. Symbiotic cyanobacteria also seem to be found more frequently in sponges growing in warm and tropical waters than in those of cold climates. The role of cyanobacterial symbionts may be in protecting the host animal from sunlight (133). In this way certain sponges have the capacity to colonise more diverse areas than those without these photoautotrophic symbionts. Cyanosymbionts have also been shown to make some of their fixed carbon available to the host sponge, enabling the sponge to have a potentially higher growth rate (137). The ecological advantage of such symbiotic associations may even extend to the production of allelochemicals by the symbiotic cyanobacteria, a group of organisms known for their production of strongly biologically active secondary metabolites, enabling the sponge to fight neighbouring organisms and thus maintain the specificity of a habitat. Even though this is plausible, and overgrowth of corals e.g., by Neofibularia irata (Biemnidae), has been observed (128), no data is available to prove or disprove such a contention.

Regarding secondary metabolite biosynthesis, symbiotic systems, as found in marine invertebrates, pose a rather difficult question concerning the true producer(s) of the chemicals ( 138 , 139). Often, if the isolated natural product is structurally similar to a known class of microbial metabolite or is found in several, taxonomically unrelated organisms, the suggestion is made that they may derive from microbial symbionts. Experimental proof, however, is difficult to obtain. In the case of filter feeders such as sponges, which digest microbes and organic material present in the water column, secondary metabolites could originate from the food source, as observed for seafood toxins in fish and molluscs, or be produced by symbionts in the tissue of the host.

Two methods have been tried to establish the true origin of some marine natural products: (i) to isolate and culture micro-organisms from invertebrates, and analyse their secondary metabolite production, and (ii) to separate the different cell types of field collected samples, either by gradient-centrifugation or using a flow cytometer (cell sorter), for further analytical studies.
With the first method, diketopiperazines, first obtained from the sponge Tedania ignis (Tedaniidae) were detected in the culture broth of Micrococcus sp., (Microccoceae) a microorganism isolated from the sponge. Unfortunately, these compounds are known as very common degradation products of proteins and are thus thought to be too nonspecific to draw clear conclusions (140). In a second case, Vibrio sp., (Vibrionaceae) were isolated from the sponge Dysidea sp., (Dysideidae) and shown to produce brominated biphenyl ethers, compounds formerly attributed to the sponge (141). There is some doubt as to whether the isolated analysis of the symbiotic parterns is able to give an answer to the complicated question of which partner plays which role in the production of the secondary metabolites. Unfortunately, for organisms such as sponges, which often have a highly convoluted surface, there are no easy methods to remove surface contamination, e.g., surface sterilisation with formaldehyde, as is done when isolating endophytic fungi from plants. Standard microbial isolation techniques also tend to select rather non-specific microorganisms, and the selected culture conditions might not be suited for the biosynthesis of the natural products.

The second methodology which looks at separated cells, does not consider the possibility that compounds may not be stored where they are produced or any exchange of biosynthetic precursors between the partners. Still, the detection, by the Faulkner group, of polychlorinated amino acid derived metabolites and of a brominated biphenyl ether in only the cyanobacterial cells [Oscillatoria spongeliae (Oscillatoriaceae)] and of sesquiterpenes in the animal tissue of Dysidea herbacea (Dysideidae) is the first strong evidence that microbial symbionts can indeed play a major role in secondary metabolite production $(62,63)$. In this latter case, morphological examinations made it clear that substantial amounts of microbial tissue were present in the sponge, thus making the biochemical result even more plausible. A further study investigated the distribution of brominated long-chain fatty acids in sponge and symbiont cell types from the tropical sponge Amphimedon terpenensis (Niphatidae). Through separation of sponge/ symbiont cells by gradient centrifugation, the presence of brominated long-chain fatty acids and phytanic acid in sponge cells only, was suggested (142).

Other approaches to the detection of natural products in situ in the tissue of the producing organisms employ chemical or physical means. This has been achieved by energy-dispersive $\mathrm{X}$-ray analysis of the brominated metabolites aerothionin and homoaerothionin, which could be clearly located in the sponge cells of Aplysina fistularis (Aplysinidae) and not in symbiotic bacterial cells (143). The storage site of the cytotoxic metabolite avarol (117), which occurs in high levels in the tissue of Dysidea avara (Dysideidae) was demonstrated by chemical and ultrastructural studies to be most probably present in spherular cells with small amounts being released into the surrounding tissue. The authors suggest that avarol might be involved in the control of bacterial symbiont growth (144). Direct chemical detection in tissue sections should be more widely applied, especially if chemicals which selectively stain certain natural products can be found. These investigations would also serve to broaden the knowledge of the site of storage of certain marine secondary metabolites. 


\section{Epibiosis}

Marine micro-organisms living on the surface of macroorganisms, so called epibionts, reportedly play an important role in the ecosystem $(145,146)$. As fouling organisms they often have detrimental effects on their substrate and various defence mechanisms of the macro-organisms, e.g., removal by mucus production or shedding of the epidermal cells, have been observed (145). Biologically active secondary metabolites are a further obvious defence strategy used by certain marine organisms, e.g., sponges, macroalgae, and soft corals. Extracts of the sponges Crambe crambe (Esperiopsidae), Ircinia fasciculata (Thorectidae), and Spongia officinalis (Spondiidae) were all tested for their activity against bacteria in their immediate surroundings. $C$. crambe showed the most prominent antibacterial activity. Its surface was, in contrast to that of the other two sponges, free of micro- and macroepibionts (147). The red alga Delisea pulchra (Bonnemaisoniaceae) was observed in the field to be without the usual epibionts. Subsequent chemical investigation of this alga led to the isolation of highly active halogenated furanones, which are present in the algae at high levels (148). These compounds are not only implicated in the deterrence of microbes but also in the deterrence of feeding by herbivores. Further experiments revealed that the same compounds may be useful as commercial antifouling agents (149).

Epibiotic bacteria may, on the other hand, be of vital importance for the host organism (150). The embryos of the crustaceans Palaemon macrodactylus (Palaemonidae, Palaemoninae) and Homarus americanus (Astacidae) are covered with a dense unibacterial film. These bacteria yielded after isolation, cultivation and chemical investigation the antifungal metabolites 2,3-indolinone-dione [-isatin (118)] and tyrosol (119). Association of the embryos with bacteria thus prevents fungal infection of the latter. If embryos are kept bacteria-free they quickly die due to fungal infections $(151,152)$.

Microbial films are also recognised as important factors in the settlement and metamorphosis of marine invertebrates. Recently, the red alga Lithothamnium pseudosorum (Corallinaceae) has been observed to induce settlement and metamorphosis of the crown-of-thorns starfish Acanthaster planci (Acanthasteridae). More detailed examination of this phenomenon revealed that marine bacteria on the surface of this alga are most likely the major influence on larval settlement and development, since on shards of $L$. pseudosorum treated with antibiotics, settlement rates were significantly reduced. Since bacteria alone cannot induce a response, the authors of this study suggest a three-way interaction between the alga, bacteria, and larva. Preliminary experiments suggested that this interaction is chemically based and can only occur if the alga and bacteria are found in an epibiotic relationship (153). Surface-associated bacteria have since long been suggested to favour settlement and metamorphoses of invertebrate larvae. In some cases it could be shown that they produce chemical factors which mediate this activity (154). The chemistry of such factors is, however, hardly known and thus poses interesting and rewarding problems for the future. Such chemicals might be useful for aquaculture to enhance settlement rates. A bacterial product that enables Hydractinia (Hydractinidae) larvae to settle stimulates the cation transport via $\mathrm{Na}^{+} / \mathrm{K}^{+}$ATPase, thus, any such compounds may also serve as potential pharmaceuticals $(155,156)$.

\section{Prospects}

In our opinion, marine natural products research has just started to bloom. Today, marine sources have the highest probability of yielding natural products with unprecedented carbon skeletons and interesting biological activity. Many more prospects regarding new habitats, e.g., black smokers, deep ocean samples, Antarctic areas, and the discussed epi- and symbiotic systems are still wide open for research. The vast area of research into marine micro-organisms; comprising marine bacteria, ranging from archaebacteria to gliding bacteria, fungi, and a whole range of microalgae e.g., dinoflagellates, diatoms, and protozoa, e.g., ciliates, amoebae, and flagellates, is just emerging and already showing immense potential.

Studies into the basic biology of many marine organisms will improve the culturability of both marine macro- and microorganisms, allowing laboratory researchers to do further biological and ecological experiments directly in the laboratory, as well as providing the opportunity for greater biomass to be produced for investigations of interesting and biologically active compounds. Biosynthetic studies of marine natural products are few, mainly, since they are technically and logistically difficult to undertake. Hence, the development of suitable tissue and cell culture methods could make an important contribution to our understanding of how and where many marine natural products are produced.

Further, and much more detailed studies in chemical ecology are needed to improve our understanding of underwater habitats and to help us protect delicate ecosystems from pollution and overexploitation. These studies would also assist researchers in the selection of interesting research materials with antifouling properties useful in the protection of vessels and harbour facilities (157). The spin-offs to biomedical and bioagricultural industries are also self-evident from this type of study and selection procedure.

The biggest threat to any natural products research in the future is the destruction of natural habitats. This can and does happen relatively quickly as was recently observed around Jamaica, where, in a matter of ten years flourishing tropical reefs changed to regions dominated by macroalgae (158). The reasons for this change are complex, but they are clearly related to the activities of man and not simply natural succession. The obvious consequence of such degradations is that biodiversity is rapidly disappearing a process which will be difficult to reverse. In this respect it can only be hoped that marine researchers at all levels will do their utmost to ensure that ecosystems are managed and maintained in a pristine state, so that they will be there for a long time to come for all to enjoy and study.

\section{Acknowledgements}

We would like to thank the following people for their advice and help in the preparation of this manuscript: Prof. Cindy $\mathrm{K}$. Angerhofer and Prof. A. Douglas Kinghorn, Program for Collaborative Research in the Pharmaceutical Sciences, Department of Medicinal Chemistry and Pharmacognosy, University of Illinois at Chicago, Chicago, Illinois, USA, Prof. Clifford Chang, Department of Chemistry, University of West Florida, Florida, USA, Dr. Rocky de Nys, School of Biological Sciences, 
University of NSW, Kensington, NSW, Australia, and Mr. Ulrich Höller, Institute for Pharmaceutical Biology, Technical University of Braunschweig.

\section{References}

1 Angerhofer, C. K., Pezzuto, J. M. (1993) Applications of Biotechnology for Drug Discovery and Evaluation, in: Biotechnology and Pharmacy, (Pezzuto, J. M., Johnson, M. E., Manasse, H. R., eds. ), Chapman and Hall, New York, 312-365.

2 Rinehart, K. L. (1988) Screening to Detect Biological Activity, in: Biomedical Importance of Marine Organisms, (Fautin, D. G., ed.), California Academy of Sciences, San Francisco, 13-22.

3 McConnell, O. J., Longley, R. E., Koehn, F. E. (1994) The Discovery of Marine Natural Products with Therapeutic Potential, in: The Discovery of Natural Products with Therapeutic Potential, (Gullo, V. P., ed.), Butterworth-Heinemann, Stoneham, 109-177.

${ }^{4}$ Bergmann, W., Feeny, R. J. (1950) J. Am. Chem. Soc. 72, 2809 2810.

${ }^{5}$ De Freitas, J. C., Blankemeier, L. A., Jacobs, R. S. (1984) Experientia 40,864-865.

${ }^{6}$ Reynolds, L. J., Morgan, B. P., Hite, G. A., Mihelich, E. D., Dennis, E. A. (1988) J. Am. Chem. Soc. 110, 5172-5177.

7 Wheeler, L. A., Sachs, G., De Vries, G., Goodrum, D., Woldemussie, E., Muallem, S. (1987) J. Biol. Chem. 262, 6531-6538.

8 Potts, B. C. M., Faulkner, D. J., Jacobs, R. S. (1992) J. Nat. Prod. 55, 1701-1717.

${ }^{9}$ Look, S. A., Fenical, W., Matsumoto, G. K., Clardy, J. (1986) J. Org. Chem. 51, 5140-5145.

10 Roussis, V., Wu, Z., Fenical, W., Strobel, S. A., Van Duyne, G. D., Clardy. J. (1990) J. Org. Chem. 55, 4916-4922.

1 Persinos, G. J., (ed.) 1991 Washington Insight, Sept., 15, 1991.

12 Flam, F. (1994) Science 266, 1324-1325.

13 Munro, M. H. G., Blunt, J. W., Lake, R. J., Litaudon, M., Battershill, C. N., Page, M. J. (1994) From seabed to sickbed: What are the prospects? in: Sponges, in Time and Space, (van Soest, R., van Kempen, T. M. G., Braekman, J. C., eds.), Balkema, Rotterdam, $473-484$.

14 Pettit, G. R., Herald, D. L., Gao, F., Sengupta, D., Herald, C. L. (1991)J. Org. Chem. 56, 1337-1340.

15 Rinehart, K. L., Holt, T. G., Fregeau, N. L., Keifer, P. A., Wilson, G. R., Perun, T. J., Sakai, R., Thompson, A. G., Stroh, J. G., Shield, L. S., Seigler, D. S., Li, L. H., Martin, D. G., Grimmelikhuijzen, C. P. J., Gäde, G. (1990) J. Nat. Prod. 53, 771-792.

${ }^{16}$ Dorr, F. A., Kuhn, J. G., Phillips, J., Von Hoff, D. D. (1988) Eur. J. Cancer Clin. Oncol. 24, 1699-1706.

${ }^{17}$ Gunawardana, G. P., Kohmoto, S., Gunasekera, S. P., McConnell, O. J., Koehn, F. E. (1988) J. Am. Chem. Soc. 110, 4856-4858.

18 Kinnel, R. B., Gehrken, H. -P., Scheuer, P. J. (1993) J. Am. Chem. Soc. $115,3376-3377$.

${ }^{19}$ Gunasekera, S. P., Cranick, S., Longley, R. E. (1989) J. Nat. Prod. 52, $757-761$.

${ }^{20}$ Hamann, M. T., Scheuer, P. J. (1993) J. Am. Chem. Soc. 115, 5825-5826.

21 Gunasekera, S. P., Gunasekera, M., Longley, R. E., Schulte, G. K. (1990) J. Org. Chem. 55, 4912-4915.

${ }^{22}$ Longley, R. E., Caddigan, D., Harmody, D., Gunasekera, M., Gunasekera, S. P. (1991) Transplantation 52, 650-656.

${ }^{23}$ Longley, R. E., Caddigan, D., Hermody, D., Gunasekera, M., Gunasekera, S. P. (1991) Transplantation 52,656-661.

${ }^{24}$ Koehn, F. E., Longley, R. E., Reed, J. K. (1992) J. Nat. Prod. 55, 613-619.

${ }^{25}$ Koehn, F. E., McConnell, O. J., Longley, R. E., Sennett, S. H., Reed, J. K. (1994) J. Med. Chem. 37, 3181-3186.

${ }^{26}$ Sakai, R., Stroh, J. G., Sullins, D. W., Rinehart, K. L. (1995) J. Am. Chem. Soc. 117, 3734-3748.

27 Suffness, S. M., Pezzuto, J. M. (1991) Assays for Cytotoxicity and Antitumour Activity, in: Methods of Plant Biochemistry, Vol. 6 , (Hostettmann, K., ed. ), Academic Press, London, 71-133.
${ }^{28}$ Coval, S. J., Conover, M. A., Mierzwa, R., King, A., Puar, M. S., Phife, D. W., Pai, J. K., Burrier, R. E., Ahn, H.-S., Boykow, G. C., Patel, M., Pomponi, S. A. (1995) Biorg. Med. Chem. Lett. 5, 605-610.

29 Patil, A. D., Kumar, N. V., Kokke, W. C., Bean, M. F., Freyer, A. J., De Brosse, C., Mai, M., Truneh, A., Faulkner, D. J., Carte, B., Breen, A. L., Hertzberg, R. P., Johnson, R. K., Westley, J. W., Potts, B. C. M. (1995) J. Org. Chem. 60, 1182-1188.

30 Pathirana, C., Stein, R. B., Berger, T. S., Fenical, W., laniro, T., Mais, D. E., Torres, A. Goldman, M. E. (1995) Mol. Pharmacol. 47. 630-635.

${ }^{31}$ Faulkner, D. J. (1992) Chemical Defenses in Marine Molluscs, in: Ecological Roles of Marine Natural Products, (Paul, V. J., ed. ), Comstock Publishing Associates, Ithaca and London, 119-163.

32 Naylor, S., Hanke, F. J., Manes, L. V., Crews, P. (1983) Chemical and Biological Aspects of Marine Monoterpenes, in: Progress in the Chemistry of Organic Natural Products, (Herz, W., Grisebach, H., Kirby, G. W., eds. ), Springer Verlag, Vol. 44, 189-241.

${ }^{33}$ König, G. M., Wright, A. D., Sticher, O. (1990) J. Nat. Prod. 53 , 1615-1618.

${ }^{34}$ Mynderse, J. S., Faulkner, D. J. (1978) Phytochemistry 17, 237 240.

${ }^{35}$ Coll, J. C., Skelton, B. W., White, A. H., Wright, A. D. (1988) Aust. J. Chem. 41, 1743-1753.

36 Wright, A. D. (1989) Ph. D. thesis, James Cook University, Queensland, Australia, 81-83.

37 De Nys, R., Coll, J. C., Price, I. R. (1991) Mar. Biol. 108, 315-320.

38 Paul, V. J., Van Alstyne, K. L. (1988) Coral Reefs 6, 263-269.

${ }^{39}$ Horton, P., Inman, W. D., Crews, P. (1990) J. Nat. Prod. 53 , $143-151$.

40 Unson, M. D., Rose, C. B., Faulkner, D. J., Brinen, L. S., Steiner, J. R., Clardy, J. (1993) J. Org. Chem. 58, 6336-6343.

41 Sharma, G. M., Vig, B. (1972) Tetrahedron Lett. 1715-1718.

42 Carté, B., Faulkner, D. J. (1981) Tetrahedron 37, 2335-2339.

43 Norton, R. S., Croft, K. D., Wells, R. J. (1981) Tetrahedron 37, 2341-2349.

${ }^{44}$ Krebs, H. C. (1986) Recent Developments in the Field of Marine Natural Products with Emphasis on Biologically Active Compounds, in: Progress in the Chemistry of Organic Natural Products, (Herz, W., Grisebach, H., Kirby, G. W., eds.), Springer Verlag, Vol. 49, $152-363$.

45 Kazlauskas, R., Lidgard, R. O., Wells, R. J., Vetter, W. (1977) Tetrahedron Lett. 3183-3186.

46 Hofheinz, W., Oberhänsli, W. E. (1977) Helv. Chim. Acta 60, $660-669$.

47 Kazlauskas, R., Murphy, P. T., Wells, R. J. (1978) Tetrahedron Lett. $4945-4948$.

48 Lee, G. M., Molinski, T. F. (1992) Tetrahedron Lett. 33, 7671 7674.

49 Charles, C., Braekman, J. C., Daloze, O., Tursch, B. (1978) Tetrahedron Lett. 1519-1520.

50 Clark, W. D., Crews, P. (1995) Tetrahedron Lett. 36, 1185-1188.

51 Erickson, K. L., Wells, R. J. (1982) Aust. J. Chem. 35, 31-38.

52 Isaacs, S., Berman, R., Kashman, Y., Gebreyesus, T., Yosief, T. (1991) J. Nat. Prod. 54, 83-91.

53 Carmely, S., Gebreyesus, T., Kashman, Y., Skelton, B. W., White, A. H., Yosief, T. (1990) Aust. J. Chem. 43, 1881-1888.

54 Orjala, J., Gerwick, W. H. (1995) Barbamide, a chlorinated metabolite with molluscicidal activity from the Caribbean cyanobacterium, Lyngbya majuscula, in: Symposium Proceedings, 8th International Symposium on Marine Natural Products, September 10-15, 1995, Santa-Cruz de Tenerife, Tenerife, Spain, 245.

55 Charles, C., Breakman, J. C., Daloze, O., Tursch, B., Declercq, J. P., Germain, G., Van Meerssche, M. (1978) Bull. Soc. Chim. Belg. 87, $481-486$.

56 Kazlauskas, R., Murphy, P. T., Wells, R. J. (1978) Tetrahedron Lett. 4949-4950.

57 Dunlop, R. W., Kazlauskas, R., March, G., Murphy, P. T., Wells, R. J. (1982) Aust. J. Chem. 35, 95-103. 
58 Sarma, N. S., Rambabu, M., Anjaneyulu, A. S. R., Rao, C. B. S., Saito, J. (1986) Ind. J. Chem. 25B, 1001-1003.

59 Searle, P. A., Jamal, N. M., Lee, G. M., Molinski, T. F. (1994) Tetrahedron 50, 3879-3888.

${ }^{60}$ Kashman, Y., Zviely, M. (1979) Tetrahedron Lett. 3879-3882.

61 Kashman, Y., Zviely, M. (1980) Experientia 36, 1279.

62 Unson, M. D., Faulkner, D. J. (1993) Experientia 49, 349-353.

63 Unson, M. D., Holland, N. D., Faulkner, D. J. (1994) Mar. Biol. 119, $1-11$.

${ }^{64}$ Thompson, J. E., Murphy, P. T., Bergquist, P. R., Evans, E. A. (1987) Biochem. Syst. Ecol. 15, 595-606.

65 Sennett, S. H., Pomponi, S. A., Wright, A. E. (1992) J. Nat. Prod. 55, 1421-1429.

${ }^{66}$ Ciavatta, M. L., Trivellone, E., Cimino, G., Uriz, M. J. (1994) Tetrahedron Lett. 35, 7871-7874.

67 De Nys, R., Steinberg, P., Rogers, C. N., Charlton, T. S., Duncan, M. W. (1995) Mar. Ecol. Prog. Ser., in press.

${ }^{68}$ Fenical, W., Jensen, P. R. (1993) Marine Micro-organisms. A New Biomedical Resource, in: Marine Biotechnology, (Attaway, D. H., Zaborsky, O. R., eds.), Plenum Press, New York, 419-457.

${ }^{69}$ Jensen, P. R., Fenical, W. (1994) Ann. Rev. Microbiol. 48, 559-584.

${ }^{70}$ Fenical, W. (1993) Chem. Rev. 93, 1673-1683.

71 Tamplin, M. L. (1990) A Bacterial Source of Tetrodotoxins and Saxitoxins, in: Marine Toxins: Origin, Structure, and Molecular Pharmacology, (Hall, S., Strichartz, G., eds.), ACS Symposium Series 418, Washington, DC, 78-86.

72 Pathirana, C., Jensen, P. R., Dwight, R., Fenical, W. (1992) J. Org. Chem. 57, 740-742.

73 Pathirana, C., Dwight, R., Jensen, P. R., Fenical, W., Delgado, A., Brinen, L. S., Clardy, J. (1991) Tetrahedron Lett. 32, 7001-7004.

74 Pathirana, C., Jensen, P. R., Fenical, W. (1992) Tetrahedron Lett. 33, 7663-7666.

75 Pathirana, C., Tapiolas, D., Jensen, P. R., Dwight, R., Fenical, W. (1991) Tetrahedron Lett. 32, 2323-2326.

76 Fenical, W., Jensen, P. R. (1995) Natural Products Chemistry of Marine Micro-organisms, in: Symposium Proceedings, 8th International Symposium on Marine Natural Products, September 10-15, 1995, Santa-Cruz de Tenerife, Tenerife, Spain, 31.

77 Giovannoni, S. J., Britschgi, T. B., Moyer, C. L., Field, G. F. (1990) Nature 345, 60-62.

${ }^{78}$ Needham, J., Kelly, M. T., Ishige, M., Andersen, R. J. (1994) J. Org. Chem. 59, 2058-2063.

79 Trischman, J. A., Jensen, P. R., Fenical, W. (1994) Tetrahedron Lett. 35, 5571-5574.

80 Takahashi, C., Takada, T., Yamada, T., Minoura, K., Uchida, K., Matsumura, E., Numata, A. (1994) Tetrahedron Lett. 35, 5013-5014.

${ }^{81}$ De Vries, D. J., Hall, M. R. (1994) Drug Development Research 33, 161-173.

${ }^{82}$ Newman, D. J., Jensen, P. R., Clement, J. J., Acebal, C. (1989) Novel activities from marine-derived micro-organisms, in: Novel Microbial Products for Medicine and Agriculture, (Demain, A. L., Somkuti, G. A., Hunter-Cevera, J. C., Rossmoore, H. W., eds.), Society for Industrial Microbiology, 239-251.

${ }^{83}$ Kobayashi, J., Ishibashi, M. (1993) Chem. Rev. 93, 1753-1769.

${ }^{84}$ Flynn, E. H. (1972) Cephalosporins and Penicillins, Academic Press, New York and London.

${ }^{85}$ Okutani, K. (1977) Bulletin of the Japanese Society of Scientific Fisheries 43, 995-1000.

${ }^{86}$ Shin, J., Fenical, W. (1987) Phytochemistry 26, 3347.

${ }^{87}$ Miller, J. D. (1986) Secondary Metabolites in Lignicolous Marine Fungi, in: The Biology of Marine Fungi, (Moss, S. T., ed.), Cambridge University Press, Cambridge, 61-67.

88 Strongman, D. B., Miller, J. D., Calhoun, L., Findlay, J. A., Whitney, N. J. (1987) Bot. Mar. 30, 21-26.

${ }^{89}$ Kupka, J., Anke, T., Steglich, W., Zechlin, L. (1981) J. Antibiot. 34, $298-304$
90 Furuya, K., Okudaira, M., Shindo, T., Sato, A. (1985) Sankyo Kenkyusho Nempo 37, 140-142.

91 Kondo, M., Takayama, T., Furuya, K., Okudaira, M., Hayashi, T., Kinoshita, M. (1987) Sankyo Kenkyusho Nempo 39, 45-53.

92 Schiehser, G. A., White, J. D., Matsumoto, G., Pezzanite, J. O., Clardy, J. (1986) Tetrahedron Lett. 27, 5587-5590.

${ }_{93}$ Pallenberg, A. J., White, J. D. (1986) Tetrahedron Lett. 27. 5591-5594.

94 Poch, G. K., Gloer, J. B. (1989) Tetrahedron Lett. 30, 3483-3486.

95 Guerriero, A., D'Ambrosio, M., Cuomo, V., Pietra, F. (1991) Helv. Chim. Acta 74, $1445-1450$.

96 Guerriero, A., D'Ambrosio, M., Cuomo, V., Vanzanella, F., Pietra, F. (1989) Helv. Chim. Acta 72, 438-446.

97 Guerriero, A., D'Ambrosio, M., Cuomo, V., Vanzanella, F., Pietra, F. (1988) Helv. Chim. Acta 71, 57-61.

98 Poch, G. K., Gloer, J. B. (1989) J. Nat. Prod. 52, 257-260.

99 Poch, G. K., Gloer, J. B. (1991) J. Nat. Prod. 54, 213-217.

100 Xu, X., de Guzman, F. S., Gloer, J. B., Shearer, C. A. (1992) J. Org. Chem. 57, 6700-6703.

101 Kohlmeyer, J., Kohlmeyer, E. (1979) in: Marine Mycology: The Higher Fungi, Academic Press, New York, London, 54-69.

102 Numata, A., Takahashi, C., Ito, Y., Takada, T., Kawai, K., Usami, Y., Matsumura, E., Imachi, M., Ito, T., Hasegawa, T. (1993) Tetrahedron Lett. 34, 2355-2358.

103 Takahashi, C., Numata, A., Ito, Y., Matsumura, E., Araki, H., Iwaki, H., Kushida, K. (1994) J. Chem. Soc. Perkin Trans. I, 1859-1864.

${ }^{104}$ Takahashi C., Takai, Y., Kimura, Y., Numata, A., Shigematsu, N., Tanaka, H. (1995) Phytochemistry 38, 155-158.

${ }_{105}$ Kirk, P. W., Catalfomo, P. (1970) Phytochemistry 9, 595-597.

106 Catalfomo, P., Block, J. H., Constantine, G. H., Kirk, P. W. (1972-73) Marine Chemistry 1, 157-162.

107 Kirk, P. W., Catalfomo, P., Block, J. H., Constantine, G. H. (1974) Veröff. Inst. Meeresforsch. Bremerh. suppl., 5, 509-518.

108 Peters, J. E., Catalfomo, P., Constantine, G. H., Kirk, P. W. (1975) J. Pharm. Sci. 64, 176-177.

109 Alam, M., Jones, E. B. G., Hossain, M. B., Van der Helm, D. (1995) Isolation and structure of a tricyclic sesquiterpene from the marine fungus Kallichroma tethys, in: The VI International Marine Mycology Symposium, July 8-15, Univ. Portsmouth, England.

110 Shigemori, H., Wakuri, S., Yazawa, K., Nakamura, T., Sasaki, T., Kobayashi, J. (1991) Tetrahedron 47, 8529-8534.

111 Numata, A., Takahashi, C., Matsushita, T., Miyamoto, T., Kawai, K., Usami, Y., Matsumara, E., Inoue, M., Ohishi, H., Shingu, T. (1992) Tetrahedron Lett. 33, 1621-1624.

112 Sugano, M., Sato, A., Iijima, Y., Furuya, K., Haruyama, H., Yoda, K., Hata, T. (1994) J. Org. Chem. 59, 564-569.

113 Sugano, M., Sato, A., lijima, Y., Oshima, T., Furuya, K., Kuwano, H., Hata, T., Hanzawa, H. (1991) J. Am. Chem. Soc. 113, 5463-5464.

114 Kobayashi, M., Uehara, H., Matsunami, K., Aoki, S., Kitagawa, I. (1993) Tetrahedron Lett. 34, 7925-7928.

115 Cheng, X.-C., Varoglu, M., Abrell, L., Crews, P., Lobkovsky, E., Clardy. J. (1994) J. Org. Chem. 59, 6344-6348.

116 Abrell, L. M., Cheng, X.-C., Crews, P. (1994) Tetrahedron Lett. 35, 9159-9160.

117 Schaumann, K. (1974) Veröff. Inst. Meeresforsch. Bremerh. Suppl. 5, 287-300.

118 Miller, J. D., Whitney, N. J. (1981) Mar. Biol. 65, 61-68.

119 Cardellina II, J. H., Marner, F. -J., Moore, R. E. (1979) Science 204, 193-195.

${ }^{120}$ Nagle, D. G., Geralds, R. S., Yoo, H. -D., Gerwick, W. H., Kim, T. -S., Nambu, M., White, J. D. (1995) Tetrahedron Lett. 36, 1189-1192.

121 Gerwick, W. H., Proteau, P. J., Nagle, D. G., Hamel, E., Blokhin, A. Slate, D. L. (1994) J. Org. Chem. 59, 1243-1245.

122 Hamel, E., Blokhin, A. V., Nagle, D. G., Yoo, H.-D., Gerwick, W. H. (1995) Drug Development Research 34, 110-120.

${ }^{123}$ Hemscheidt, T., Puglisi, M. P., Larson, L. K., Patterson, G. M. L., Moore, R. E., Rios, J. L., Clardy, J. (1994) J. Org. Chem. 59, 3467-3471. 
${ }^{124}$ Gerwick, W. H., Lopez, A., Van Duyne, G. D., Clardy, J., Oritz, W., Baez, A. (1986) Tetrahedron Lett. 27, 1979-1982.

125 Gerwick, W. H., Jiang, Z. D., Agarwal, S. K., Farmer, B. T. (1995) Tetrahedron 48, 2313-2324.

${ }^{126}$ Gerwick, W. H., Mrozek, C., Moghaddam, M. F., Agarwal, S. K. (1989) Experientia 45, 115-121.

127 Cavanaugh, C. M. (1994) Amer. Zool. 34, 79-89.

128 Wilkinson, C. R. (1978) Mar. Biol. 49, 161-167.

129 Vacelet, J. (1975) J. Microscopie Biol. Cell 23, 271-288.

130 Rützler, K. (1990) Associations between Caribbean Sponges and Photosynthetic Organisms, in: New Perspectives in Sponge Biology, (Rützler, K., ed. ), Smithsonian Institution Press, Washington DC, $455-466$.

131 Müller, W. E. G., Zahn, R. K., Kurelec, B., Lucu, C., Müller, I., Uhlenbruck, G. (1981) J. Bacteriol, 145, 548-558.

132 Wilkinson, C. R. (1978) Mar. Biol. 49, 169-176.

133 Wilkinson, C. R. (1980) Cyanobacteria symbiotic in marine sponges, in: Endocytobiology: Endosybiosis and Cell Biology, (Schwemmler, W., Schenk, H. E. A., eds. ), Walter de Gruyter, Berlin $553-563$.

134 Wilkinson, C. R. (1978) Mar. Biol. 49, 177-185.

135 Sarà, M. (1971) Mar. Biol. 11, 214-221.

136 Rützler, K. (1988) Dis. aquat. Org. 5, 143-149.

137 Wilkinson, C. R. (1979) Nutrient Translocation from Symbiotic Cyanobacteria to Coral Reef Sponges, in: Biologie des Spongiaires, (Lêvi, C., Boury-Esnault, N., eds.), Colloques Internationaux des C.N.R.S. 291, Centre National de Recherche Scientifique, Paris $373-380$.

138 Faulkner, D. J., He, H. -Y., Unson, M. D., Bewley, C. A., Garson, M. J. (1993) Gazz. Chim. Ital. 123, 301-307.

139 Garson, M. J. (1994) The biosynthesis of sponge secondary metabolites: Why it is important, in: Sponges in Time and Space, (van Soest, R., van Kempen, T. M. G., Braekam, J. C., eds. ), Balkema, Rotterdam, 427-440.

140 Stierle, A. C., Cardellina II, J. H., Singleton, F. L. (1988) Experientia 44,1021 .

141 Elyakov, G. B., Kuznetsova, T., Mikhailov, V. V., Maltsev, I. I., Voinov, V. G., Fedoreyev, S. A. (1991) Experientia 47, 632-633.

142 Garson, M. J., Zimmermann, M. P., Battershill, C. N., Holden, J. L., Murphy, P. T. (1994) Lipids 29, 509-516.

143 Thompson, J. E., Barrow, K. D., Faulkner, D. J. (1983) Acta Zool. (Stockholm) 64, 199-210.

144 Müller W. E. G., Diehl-Seifert, B., Sobel, C., Bechthold, A., Kljajic, Z., Dorn, A. (1986) J. Histochem. Cytochem. 34, 1687-1690.

145 Wahl, M. (1989) Mar. Ecol. Prog. Ser. 58, 175-189.

146 Davis, A. R., Targett, N. M., McConnell, O. J., Young, C. M. (1989) Epibiosis of Marine Algae and Benthic Invertebrates: Natural Products Chemistry and Other Mechanisms Inhibiting Settlement and Overgrowth, in: Bioorganic Marine Chemistry, (Scheuer, P. J., ed. ), Vol, 3, 86-114, Springer, Berlin und Heidelberg.

147 Becerro, M. A., Lopez, N. I., Turon, X., Uriz, M. J. (1994) J. Exp. Mar, Biol. Ecol. 179, 195-205.

148 De Nys, R., Wright, A. D., König, G. M., Sticher, O. (1993) Tetrahedron 49, 11213-11220.

149 De Nys, R., Steinberg, P. D., Willemsen, P., Dworjanyn, S. A., Gabelish, C. L. King, R. J. (1995) Biofouling 8, 259-271.

150 Bonar, D. B., Weiner, R. M., Colwell, R. R. (1986) Microb. Ecol. 12, $101-110$

151 Gil-Turnes, M. S., Hay, M. E., Fenical, W. (1989) Science 246, $116-118$.

152 Gil-Turnes, M. S., Fenical, W. (1992) Biol. Bull, 182, 105-108.

153 Johnson, C. R., Sutton, D. C. (1994) Mar. Biol. 120, 305-310.

154 Pawlik, J. R. (1992) Induction of Marine Invertebrate Larval Settlement: Evidence for Chemical Cues, in: Ecological Roles of Marine Natural Products, (Paul, V. J. ed.), Comstock Publishing Associates, Ithaca, London, 189-236.

155 Müiller, W. A. (1973) Wilhelm Roux's Arch. Dev. Biol. 173, $107-121$
156 Müller, W. E. G., Buchal, G. (1973) Wilhelm Roux's Arch. Dev. Biol. 173, 122-135.

157 Clarc, A. (1995) New Scientist, Febr., 18, 38-41.

158 Hughes, T. P. (1994) Science 265, 1547-1551.

159 Kakeya, H., Takahashi, I., Okada, G., Isono, K., Osada, H. (1996) J. Antibiot. 48, 733-735.

${ }^{160}$ Falch, B. S., König, G. M. Wright, A. D., Sticher, O., Rüegger, H. Bernardinelli, G. (1993) J. Org. Chem. 58, 6570-6575. 